\title{
Cell- and Lamina-Specific Expression and Activity-Dependent Regulation of Type II Calcium/Calmodulin-Dependent Protein Kinase Isoforms in Monkey Visual Cortex
}

\author{
Brahim Tighilet, ${ }^{1}$ Tsutomu Hashikawa, $^{2}$ and Edward G. Jones ${ }^{1}$ \\ ${ }^{1}$ Department of Anatomy and Neurobiology, University of California, Irvine, Irvine, California 92697-1280 and ${ }^{2}$ Laboratory \\ of Brain Structure and Function, Frontier Research Program in Brain Mechanisms of Mind and Behavior, Institute of \\ Physical and Chemical Research, Wako, Saitama 351-01, Japan
}

\begin{abstract}
In situ hybridization histochemistry and immunocytochemistry were used to study localization and activity-dependent regulation of $\alpha, \beta, \gamma$, and $\delta$ isoforms of type II calcium/calmodulindependent protein kinase (CaMKII) and their mRNAs in areas 17 and 18 of normal and monocularly deprived adult macaques. CaMKII- $\alpha$ is expressed overall at levels three to four times higher than that of CaMKII- $\beta$ and at least 15 times higher than that of CaMKII- $\gamma$ and $-\delta$. All isoforms are expressed primarily in pyramidal cells of both areas, especially those of layers II-III, IVA (in area 17), and VI, but are also expressed in nonpyramidal, non-GABAergic cells of layer IV of both areas and in interstitial neurons of the white matter. CaMKII- $\alpha$ and $-\beta$ are colocalized, suggesting the formation of heteromers. There was no evidence of expression in neuroglial cells. Each isoform has a unique pattern of laminar and sublaminar distribution, but cortical
\end{abstract}

layers or sublayers enriched for one isoform do not correlate with layers receiving inputs only from isoform-specific layers of the lateral geniculate nucleus. CaMKII- $\alpha$ and $-\beta$ mRNA and protein levels in layer IVC of area 17 are subject to activitydependent regulation, with brief periods of monocular deprivation caused by intraocular injections of tetrodotoxin leading to a 30\% increase in CaMKII- $\alpha$ mRNA and a comparable decrease in CaMKII- $\beta$ mRNA in deprived ocular dominance columns, especially of layer IVC $\beta$. Expression in other layers and expression of CaMKII- $\gamma$ and $\delta$ were unaffected. Changes occurring in layer IVC may influence the formation of heteromers and protect supragranular layers from CaMKII-dependent plasticity in the adult.

Key words: plasticity; $\alpha, \beta, \gamma$, and $\delta$ isoforms; activitydependent regulation; visual deprivation; pyramidal cells; GABA
Type II calcium/calmodulin-dependent protein kinase (CaMKII) is involved in many aspects of neuronal function involving calcium signaling (Braun and Schulman, 1995), including plasticity of the cerebral cortex (Glazewski et al., 1996; Gordon et al., 1996; Kirkwood et al., 1997). This kinase exists in four known isoforms, the products of separate genes, $\alpha, \beta, \gamma$, and $\delta$ (Bennett et al., 1983; Bennett and Kennedy, 1987; Hanley et al., 1987; Lin et al., 1987; Tobimatsu et al., 1988; Tobimatsu and Fujisawa, 1989). Alternative mRNA splicing results in the production of additional isoforms (Bennett and Kennedy, 1987; Benson et al., 1991a; Mayer et al., 1993; Nghiem et al., 1993; Schworer et al., 1993; Edman and Schulman, 1994; Brocke et al., 1995). Native CaMKII is thought to consist of heteromeric and homomeric combinations of isomers, formed by interactions at the C-terminal end of the molecule (Lin et al., 1987; Yamauchi et al., 1989). Unmasking of a catalytic domain in the N-terminal half of all isoforms by $\mathrm{Ca}^{2+} /$ calmodulin permits interactions with a wide variety of substrates.

\footnotetext{
Received Nov. 11, 1997; revised Jan. 7, 1998; accepted Jan. 12, 1998.

This work was supported by Grant NS21377 from the National Institutes of Health, United States Public Health Service, and by the Frontier Research Program, Japan. B.T. was supported by a grant from Fondation Fyssen (Paris, France). We thank Drs. P. J. Isackson and K. D. Murray for providing the $\beta, \gamma$, and $\delta$ cDNAs, Drs. M. B. Kennedy and H. Schulman for providing $\alpha$ and $\beta$ antibodies, respectively, and Phong Nguyen, Clyde King Jr, and Hao Truong for expert technical assistance.

Correspondence should be addressed to Dr. Edward G. Jones, Department of Anatomy and Neurobiology, University of California, Irvine, Irvine, CA 92697-1280.

Dr. Tighilet's present address: Laboratoire de Neurobiologie des Restaurations Functionelles, University of Provence, Marseilles 20, France.

Copyright (C) 1998 Society for Neuroscience $\quad 0270-6474 / 98 / 182129-18 \$ 05.00 / 0$
}

CaMKII- $\alpha$ and $-\beta$ genes are expressed only in nervous tissue (Erondu and Kennedy, 1985), but CaMKII- $\gamma$ and $-\delta$ are expressed in other tissues as well (Tobimatsu and Fujisawa, 1989). Expression of $\alpha$ and $\beta$ is neuron-specific but varies across brain regions, CaMKII- $\alpha$ being highest in forebrain and CaMKII- $\beta$ being highest in brainstem and cerebellum (Erondu and Kennedy, 1985; Benson et al., 1992). $\gamma$ and $\delta$ isoforms also show regional differences, but whether their expression is restricted to neurons is not clear (Takaishi et al., 1992; Sakagami and Kondo, 1993). CaMKII- $\alpha$ in the forebrain is with few exceptions restricted to excitatory, glutamatergic neurons and absent from GABAcontaining (GABAergic) neurons (Benson et al., 1991b, 1992; Jones et al., 1994a,b). CaMKII- $\alpha$ forms a major component of postsynaptic densities (Kennedy et al., 1983; Goldenring et al., 1984; Kelly et al., 1984) and is exclusively located at glutamatergic synapses in the neocortex, thalamus, and hippocampus (Liu and Jones, 1996, 1997). In the hippocampus, CaMKII- $\alpha$ is associated with the induction of long-term potentiation (LTP) and potentially with other forms of synaptic plasticity (Malinow et al., 1988, 1989; Malenka et al., 1989; Silva et al., 1992; Stevens et al., 1994; Stanton and Gage, 1996).

In monkey cerebral cortex and dorsal lateral geniculate nucleus, expression of CaMKII- $\alpha$ is restricted to subpopulations of cells with specific laminar locations and connections (Jones, 1988; Benson et al., 1991b; Jones et al., 1994a; Tighilet et al., 1998). The $\beta, \gamma$, and $\delta$ isoforms have less-restricted distributions in the lateral geniculate nucleus (Tighilet et al., 1998) but have not been charted in cerebral cortex.

CaMKII- $\alpha$ expression in cortical neurons is uniquely sensitive 
to levels of activity, being upregulated when neural activity is reduced (Hendry and Kennedy, 1986; Benson et al., 1991a) and downregulated when activity is increased (Bronstein et al., 1992; Murray et al., 1995; Liang and Jones, 1997). This sensitivity may underlie the role of CaMKII- $\alpha$ in cortical plasticity. It is unknown whether the other three isoforms are affected by manipulations that alter cortical activity.

\section{MATERIALS AND METHODS}

Eleven macaque monkeys (three Macaca fascicularis, four M. mulatta, and four M. fuscata) aged 2 or more years were used. Two of the animals were normal. The remaining nine were anesthetized with ketamine, and tetrodotoxin (TTX; $15 \mu \mathrm{g}$ in $10 \mu \mathrm{l}$ of normal saline) was injected into the vitreous cavity of one eye every $4 \mathrm{~d}$ for 7,14 , or $16 \mathrm{~d}$ before death. Examination of the direct and consensual light reflexes indicated that retinal activity remained suppressed throughout the survival period. All procedures were approved by the appropriate Institutional Animal Care and Use committees.

All animals were given an overdose of Nembutal and perfused through the heart with normal saline, followed by $4 \%$ paraformaldehyde and $0.2 \%$ glutaraldehyde in $0.1 \mathrm{~m}$ phosphate buffer. The brains were postfixed overnight at $4^{\circ} \mathrm{C}$ in $4 \%$ paraformaldehyde in $0.1 \mathrm{M}$ phosphate buffer. Thereafter, blocks containing the occipital lobe were cryoprotected in $30 \%$ sucrose, frozen in dry ice, and sectioned serially at $25 \mu \mathrm{m}$ in the frontal plane or in a plane parallel to the cortex of the occipital lobe. Alternate groups of five sections were collected in sterile $4 \%$ paraformaldehyde for in situ hybridization histochemistry or in $0.1 \mathrm{~m}$ phosphate buffer for immunocytochemical, Nissl, or cytochrome oxidase (CO) staining. Every 24th or 25th section was used for hybridization with sense control riboprobes or for immunocytochemical controls.

\section{In situ hybridization}

Free-floating sections were rinsed twice in $0.75 \%$ glycine in $0.1 \mathrm{M}$ phosphate buffer, $\mathrm{pH} 7.4$, followed by a wash in $0.1 \mathrm{M}$ phosphate buffer, $\mathrm{pH}$ 7.4. They were then digested with proteinase $\mathrm{K}(0.5 \mu \mathrm{g} / \mathrm{ml}$ in $0.1 \mathrm{M}$ Tris-HCl buffer, $\mathrm{pH} 8.0$, containing $0.05 \mathrm{~m}$ EDTA) for $8-10 \mathrm{~min}$ at room temperature. Digestion was stopped with $0.25 \%$ acetic anhydride in $0.1 \mathrm{M}$ triethanolamine, $\mathrm{pH}$ 8.0. After two washes in $2 \times \mathrm{SSC}, \mathrm{pH} 7.0(1 \times \mathrm{SSC}$ consists of $0.88 \% \mathrm{NaCl}$ and $0.44 \% \mathrm{Na}_{3} \mathrm{C}_{6} \mathrm{H}_{5} \mathrm{O}_{3} \cdot 2 \mathrm{H}_{2} \mathrm{O}$ ), the sections were incubated for $1 \mathrm{hr}$ at $60^{\circ} \mathrm{C}$ in hybridization buffer consisting of $50 \%$ deionized formamide, $10 \%$ dextran sulfate, $5 \% 2 \times$ SSC, $0.9 \%$ Ficoll, $0.9 \%$ polyvinylpyrrolidone, and $0.9 \%$ bovine serum albumin. Just before use, $0.3 \mathrm{mg} / \mathrm{ml}$ herring sperm DNA, $0.15 \mathrm{mg} / \mathrm{ml}$ wheat germ tRNA, and $40 \mathrm{~mm}$ dithiothreitol (DTT) were added. Sections were then transferred to new hybridization buffer containing one of the following radiolabeled, cRNA probes.

\section{CaMKII riboprobes}

CaMKII- $\alpha$ riboprobes were transcribed from a cDNA encoding a part of monkey CaMKII- $\alpha$ that corresponds to bases $869-1185$ of the rat CaMKII- $\alpha$ gene. The cDNA also contains a 33 base insert beginning at nucleotide 984 of the rat sequence (Benson et al., 1991a). Antisense riboprobes made from this cDNA recognize both CaMKII- $\alpha$ and $\alpha-33$ mRNAs but do not recognize mRNAs for other kinase isoforms. Full details of the procedures used for isolating this and other cDNAs using synthetic oligonucleotide probes and PCR are given in Benson et al. (1991a).

CaMKII- $\beta$ riboprobes were transcribed from a 770 bp human cDNA (P. J. Isackson, unpublished) (see Tighilet et al., 1998) that corresponds to bases $550-1320$ of rat CaMKII- $\beta$ (Bennett and Kennedy, 1987). Antisense riboprobes made from this cDNA recognize both CaMKII- $\beta$ and $-\beta^{\prime}$ subunit mRNAs but do not recognize mRNAs for other kinase isoforms.

CaMKII- $\gamma$ riboprobes were transcribed from a 546 bp cDNA (P. J. Isackson and K. D. Murray, unpublished) (see Tighilet et al., 1998) that corresponds to bases 913-990 and 1060-1527 of the human $\gamma \mathrm{c}$ subunit (Nghiem et al., 1993).

CaMKII- $\delta$ riboprobes were transcribed from a 570 bp cDNA (K. D. Murray and P. J. Isackson, unpublished) (see Tighilet et al., 1998) that corresponds to bp 1213-1782 of the rat $\delta$ subunit (Tobimatsu et al., 1988).

Sense and antisense riboprobes were transcribed in the presence of $\left[\alpha-{ }^{33}\right.$ P]UTP or $\alpha{ }^{-35}$ S-UTP. All riboprobes had similar $\mathrm{G} / \mathrm{C}$ ratios and similar specific activities. The hybridization solution contained $1 \times 10^{4}$ $\mathrm{cpm} / \mu \mathrm{l}$ of riboprobe. After a $20-36 \mathrm{hr}$ incubation at $60^{\circ} \mathrm{C}$, the sections were washed sequentially as follows: twice for $30 \mathrm{~min}$ each in $4 \times \mathrm{SSC}$ at $60^{\circ} \mathrm{C}$; for $45 \mathrm{~min}$ to $1 \mathrm{hr}$ with ribonuclease A $(0.02 \mathrm{mg} / \mathrm{ml}$ in $0.01 \mathrm{M}$ Tris- $\mathrm{HCl}$ buffer, $\mathrm{pH} 8.0,1 \mathrm{~mm}$ EDTA, and $2.9 \% \mathrm{NaCl}$ ) at $45^{\circ} \mathrm{C}$; twice for $30 \mathrm{~min}$ each in $2 \times \mathrm{SSC}$ at room temperature; twice for $30 \mathrm{~min}$ each in $0.5 \times \mathrm{SSC}$ at $60^{\circ} \mathrm{C}$; and twice for $15 \mathrm{~min}$ each in $0.1 \times \mathrm{SSC}$ at room temperature.

Hybridized sections were mounted on gelatin-coated glass slides, dried, placed in contact with Amersham $\beta$-Max film, and exposed for $1-15$ d. Sections hybridized with CaMKII- $\alpha$ riboprobes were in many cases exposed for less time than were those hybridized with CaMKII- $\beta$, $-\gamma$, or $-\delta$ riboprobes (see Results). After development of the film, the slides were lipid extracted in chloroform and ethanol, dipped in Kodak NTB2 emulsion, and exposed at $4^{\circ} \mathrm{C}$ for $4-8$ weeks. The emulsion autoradiographs were developed in Kodak D-19, fixed, counterstained with cresyl violet, dehydrated, cleared, and coverslipped in DPX. Control sections hybridized with sense riboprobes showed no hybridization above a weak background level.

\section{Immunocytochemistry}

The following monoclonal antibodies or polyclonal antisera were used.

CaMKII- $\alpha$. Anti-CaMKII- $\alpha$ is a well-characterized mouse monoclonal antibody (Erondu and Kennedy, 1985) specific for the $\alpha$ subunit. It was a gift from Dr. M. B. Kennedy and was also obtained from Boehringer Mannheim (Indianapolis, IN).

CaMKII- $\beta$. Two antibodies to CaM KII- $\beta$ were used. A rat monoclonal antibody, $\mathrm{cB} \beta-1$, characterized in Scholz et al. (1988), was a gift from Dr. H. Schulman. A goat polyclonal antiserum raised against a peptide corresponding to amino acids 521-540 at the C-terminal end of mouse CaMKII- $\beta$ was obtained from Santa Cruz Biotechnology (Santa Cruz, CA).

CaMKII- $\gamma$. A goat polyclonal antiserum raised against a peptide corresponding to amino acids $478-495$ at the C-terminal end of human CaMKII- $\gamma$ was obtained from Santa Cruz Biotechnology.

$C a M K I I-\delta$. A goat polyclonal antiserum raised against a peptide corresponding to amino acids 515-533 at the C-terminal end of rat CaMKII- $\delta$ was obtained from Santa Cruz Biotechnology.

All antibodies were diluted 1:500, except anti-CaM KII- $\alpha$ which was diluted 1:1000. Sections were preincubated in $0.05 \%$ Triton X-100 and $3 \%$ normal serum in $0.1 \mathrm{M}$ phosphate buffer. They were transferred to the same solution to which the diluted antibody or antiserum had been added. After $36-48 \mathrm{hr}$ at $4^{\circ} \mathrm{C}$, the sections were treated with avidinbiotin peroxidase kits (Vector Laboratories, Burlingame, CA) and reacted in $0.05 \% 3,3^{\prime}$-diaminobenzidine-tetrahydrochloride plus $0.01 \%$ $\mathrm{H}_{2} \mathrm{O}_{2}$ to visualize bound antibodies. Control sections were incubated in $0.1 \mathrm{M}$ phosphate buffer, $\mathrm{pH} 7.4$, containing normal serum instead of the primary antibody and showed no staining above a weak, nonspecific background. The sections were finally mounted on gelatin-coated slides, dehydrated, and coverslipped. Adjacent sections were reacted for cytochrome oxidase or mounted and stained with $0.25 \%$ thionin.

For double immunocytochemical staining, the indirect immunofluorescent technique was used. To examine potential colocalization of CaMKII- $\alpha$ and CaMKII- $\beta$, sections were incubated simultaneously in mouse anti-CaMKII- $\alpha$ and rat anti-CaMKII- $\beta$ at the same concentrations given above, in $0.1 \mathrm{M}$ phosphate buffer containing $3 \%$ goat serum, $3 \%$ rabbit serum, and $0.24 \%$ Triton $\mathrm{X}-100$, for $24 \mathrm{hr}$ at $4^{\circ} \mathrm{C}$. After washing, the sections were incubated in a mixture of 1:100 rhodamineconjugated goat anti-mouse IgG (Chemicon, Temecula, CA) and 1:100 fluorescein-conjugated rabbit anti-rat $\operatorname{IgG}$ (Vector) in phosphate buffer containing $3 \%$ goat serum, $3 \%$ rabbit serum, and $0.25 \%$ Triton X-100. Sections were mounted under coverslips on glass slides in a 1:3 mixture of $0.1 \mathrm{M}$ phosphate buffer and glycerol. To demonstrate the lack of colocalization of CaMKII- $\alpha$ or CaMKII- $\beta$ with GABA, sections were incubated first for $24 \mathrm{hr}$ at $4^{\circ} \mathrm{C}$ in a mixture of $1: 3000$ mouse antiCaMKII- $\alpha$ and 1:5000 rabbit anti-GABA antiserum (Sigma, St. Louis, $\mathrm{MO}$ ) in $0.1 \mathrm{M}$ phosphate buffer containing $3 \%$ horse serum, $2 \%$ bovine serum albumin, and $0.25 \%$ Triton $\mathrm{X}-100$. After washing, sections were reincubated in a mixture of 1:100 fluorescein-conjugated horse antimouse (Vector) and 1:100 rhodamine-conjugated donkey anti-rabbit (Chemicon) IgGs in $0.1 \mathrm{~m}$ phosphate buffer containing $3 \%$ horse serum, $2 \%$ bovine serum albumin, and $0.25 \%$ Triton $\mathrm{X}-100$. Other sections were incubated first in a mixture of 1:500 rat anti-CaM KII- $\beta$ and 1:500 rabbit anti-GABA, followed by a mixture of 1:100 fluorescein-conjugated rabbit anti-rat (Vector) and 1:100 rhodamine-conjugated donkey antirabbit (Chemicon) IgGs in $0.1 \mathrm{M}$ phosphate buffer containing $3 \%$ rabbit 
serum, $2 \%$ bovine serum albumin, and $0.25 \%$ Triton $\mathrm{X}-100$. All sections were mounted in glycerol and phosphate buffer as described above. Sections were then examined in an epifluorescence microscope equipped with fluorescein- and rhodamine-exciting filters. It was not possible to obtain double staining for CaMKII- $\gamma$ or CaMKII- $\delta$ and the other two isoforms or for CaMKII- $\gamma$ or CaMKII- $\delta$ and GABA.

\section{Quantification}

At least one film autoradiogram from each normal and monocularly deprived animal, showing the results of hybridization with each probe, was quantified by densitometry using a microcomputer imaging device (MCID/M4; Imaging research, Inc., St. Catharines, Ontario, Canada). Optical density readings were taken in scans of defined width across the thickness of areas 17 or 18 from pia mater to white matter or in tangential sections across several ocular dominance columns in layer IVC. The laminae of the cortex were then identified by comparison with digitized images of adjacent Nissl-stained sections, and ocular dominance columns were identified by comparison with similarly digitized images of the relevant parts of adjacent CO-stained sections. Background readings were taken over the white matter subjacent to the cortex and subtracted from readings taken over the cortex. Absolute values of radioactivity were determined from ${ }^{14} \mathrm{C}$ plastic standards (Amersham, Arlington Heights, IL) exposed on the same sheet of film. No attempt was made to quantify the immunocytochemical preparations.

\section{RESULTS}

\section{Levels of CaMKII mRNAs in normal visual cortex}

In both areas 17 and 18, the highest levels of expression were observed for CaMKII- $\alpha$ mRNA. CaMKII- $\beta,-\gamma$, and $-\delta$ mRNAs were more weakly expressed, with $\beta$ being stronger than $\gamma$ and $\delta$. Autoradiograms for the latter two commonly had to be exposed for longer times to visualize patterns of laminar distribution. Optical density measurements made on sections from the same brains hybridized at the same time and exposed for the same period on the same piece of film gave the following mean figures for levels of each mRNA (in $\mathrm{nCi}$ per $\mathrm{gm}$ ): for CaMKII- $\alpha$ in area $17,2007.53 \pm 109.17$, and in area 18, 1510.71 \pm 93.67; for CaMKII- $\beta$ in area $17,635.18 \pm 18.13$, and in area $18,599.71 \pm$ 3.88; for CaMKII- $\gamma$ in area $17,149.68 \pm 2.95$, and in area 18, $138.02 \pm 8.97$; and for CaMKII- $\delta$ in area $17,157.08 \pm 9.12$, and in area $18,131.07 \pm 7.12$.

Apart from different densities overall, patterns of labeling in relation to cortical layers and sublayers in areas 17 and 18 were unique for each subunit mRNA (Figs. $1 A, 2$ ) and will be described sequentially below. For CaMKII- $\alpha$ mRNA, intense autoradiographic labeling was seen on film autoradiograms after an exposure of only 2-3 d. Effective labeling could be detected for CaMKII- $\beta$ after 2-3 d, but more intense labeling was obtained after 5-8 d. Effective laminar labeling for CaMKII- $\gamma$ and CaMKII- $\delta$ mRNAs required exposure times of 11-15 d.

\section{Laminar distribution of CaMKII mRNAs in normal visual cortex}

Localization of CaMKII- $\alpha$ mRNA across layers of areas 17 and 18 was in conformity with previous descriptions (Benson et al., 1991a), but patterns of expression of CaMKII- $\beta,-\gamma$, and $-\delta$ were quite unlike that of CaMKII- $\alpha$. CaMKII- $\alpha$ is expressed most highly in cells of layers II-III, IVA, and VI in area 17 and in cells of layers II-III and VI in area 18. CaMKII- $\beta$ in area 17 was expressed most heavily in cells of layers IVA, IVC, and VI and less heavily in cells of layers II-III. In area 18 , CaMKII- $\beta$ was expressed mainly in layers IIIB and VI. CaMKII- $\gamma$, although much less densely expressed, had a laminar pattern more similar to that of CaMKII- $\beta$ than of CaMKII- $\alpha$, whereas CaMKII- $\delta$ was more similar to CaMKII- $\alpha$ in laminar pattern but with the relative densities in layers II-III and layer VI reversed. In the sections that follow, areas 17 and 18 will be described serially, and their layers will be given in order of highest to lowest density of labeling.

\section{CaMKII- $\alpha$}

Area 17. Autoradiographic labeling for CaMKII- $\alpha$ mRNA was densest in layer II and in the upper two-thirds of layer III (Figs. $1 A, 3 A)$. Superficial to the dense band of labeling corresponding to these layers, layer I was unlabeled. A zone of relatively weaker labeling characterized the deepest aspect of layer III; this was replaced deeply by a dense band of labeling corresponding to layer IVA. Layer IVB was weakly labeled; then labeling increased somewhat in layer IVC $\alpha$ and increased further in layer IVC $\beta$, forming a thin dense band in which hybridization intensity was approximately the same as that observed in deep layer III. The weakest density of labeling, apart from layer I, was found in layer V. Labeling began to increase in the deep part of layer V and became intense again in layer VI, particularly in its superficial part. The border between layer VI and the underlying white matter was not sharply defined, labeling falling off gradually into the superficial $100 \mu \mathrm{m}$ of the white matter. In this region, a large number of individually labeled cells could be detected.

When examined in dark field in emulsion autoradiographs (Fig. $3 A$ ), the labeling pattern for CaMKII- $\alpha$ mRNA was characteristically diff use, as reported previously (Burgin et al., 1990; Benson et al., 1991a; Jones et al., 1994b). The presence of large amounts of the mRNA in dendrites obscures the labeling of individual cell somata, except when inspected at high magnification (Fig. 4A). Only the labeling of large somata in layer IVA was distinct at low magnification (Fig. 3A).

Area 18. Labeling with CaMKII- $\alpha$ riboprobes was distinguished by the presence of two major bands of hybridization, one corresponding to deep layer III and the other to layer VI (Figs. $1 A, 3 B)$. Large labeled cell somata could be detected in both bands, but labeling was, as in area 17 , generally diffuse.

\section{CaMKII- $\beta$}

Area 17. The densest labeling was observed in layer VI (Fig. $1 B$ ). A high density was also detected in layer IVC, and there was a thin band of relatively high density in layer IVA. A moderate density of labeling was present in layers II and III. The weakest labeling was in layers I, IVB, and V, although a thin line of slightly enhanced labeling could be detected in deep layer $\mathrm{V}$. Labeling was not diffuse like that observed with CaMKII- $\alpha$ mRNA labeling, and individual cell somata were clearly defined by overlying silver grains, the labeling of the neuropil being much less than that with CaMKII- $\alpha$ riboprobes (Figs. 3C, 4B).

Area 18. Two peaks of denser labeling corresponded to deep layer III and layer VI (Figs. $1 B, 3 D$ ). In these layers, large neuronal somata were clearly labeled. Labeling was relatively weak in layer II and the remainder of layer III and in layers IV and $\mathrm{V}$, although a thin band of enhanced labeling could be seen at the border of layers IV and V. This contained a line of interrupted large, labeled cell somata.

\section{CaMKII- $\gamma$}

Area 17. Labeling for CaMKII- $\gamma$ mRNA was weak, but there was one band of heightened labeling that corresponded to layer VI, especially to its superficial half (Fig. 1C). Here, labeled cell somata could be seen. Other faintly enhanced bands of labeling could be detected in layers IVA and IVC (Figs. 1C, 3E). Layers II and superficial III showed some enhancement of labeling, and 

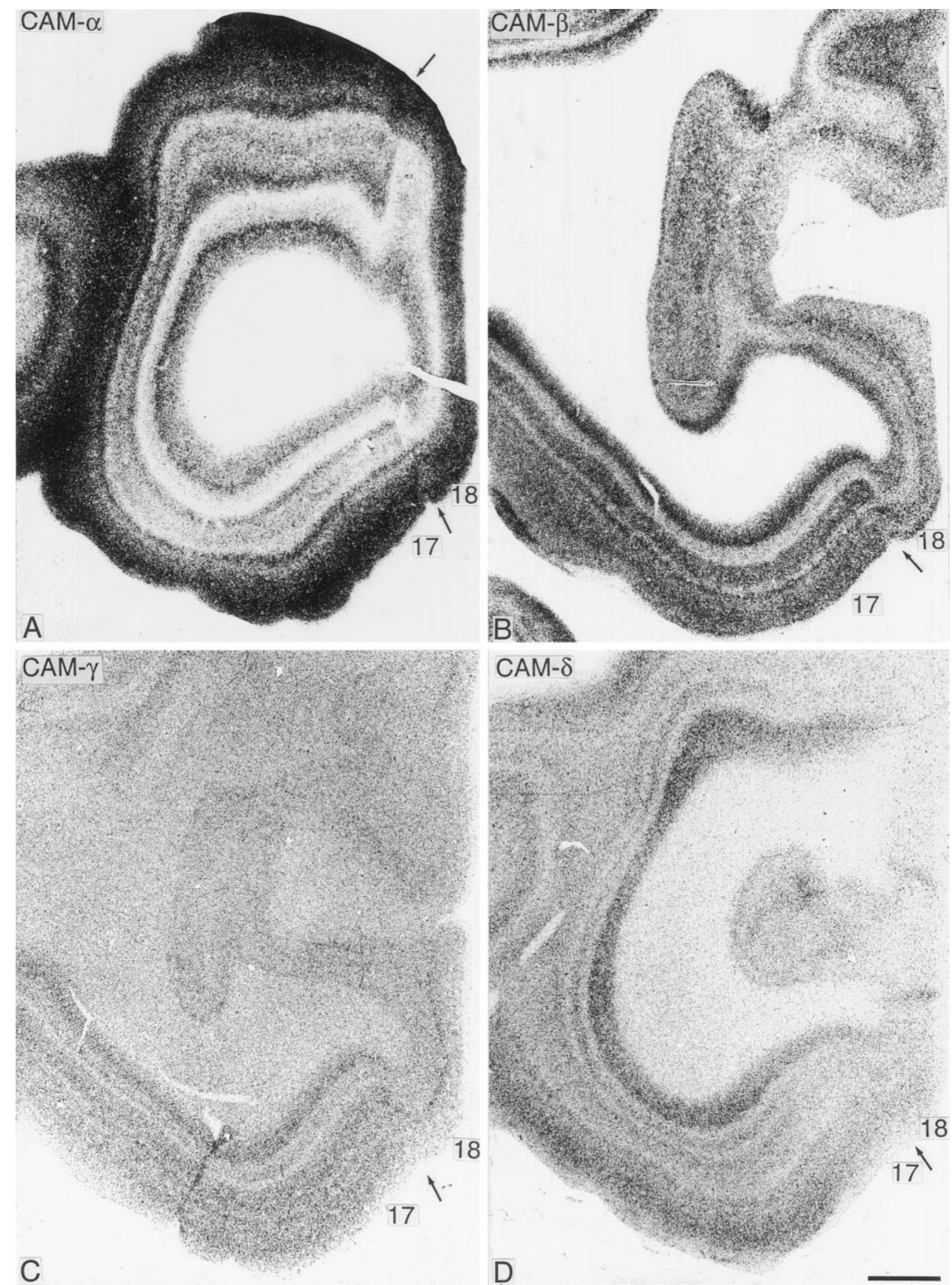

Figure 1. Autoradiograms of surface parallel sections near the occipital pole of the same $M$. fuscata brain that were hybridized to radioactive RNA probes complementary to CaMKII- $\alpha(C A M-\alpha)$, CaMKII- $\beta(C A M-\beta)$, CaMKII- $\gamma(C A M-\gamma)$, and CaMKII- $\delta(C A M-\delta)$ mRNAs. $A$ is more superficial than $B-D$ which are closely adjacent to one another. Arrows indicate the border between areas 17 and 18 . $A$ was exposed for $3 \mathrm{~d}, B$ was exposed for $5 \mathrm{~d}$, and $C$ and $D$ were exposed for $11 \mathrm{~d}$ to reveal laminar densities of hybridization. For true relative differences in overall densities of expression, see Figure 2. Scale bar, $1 \mathrm{~mm}$. 

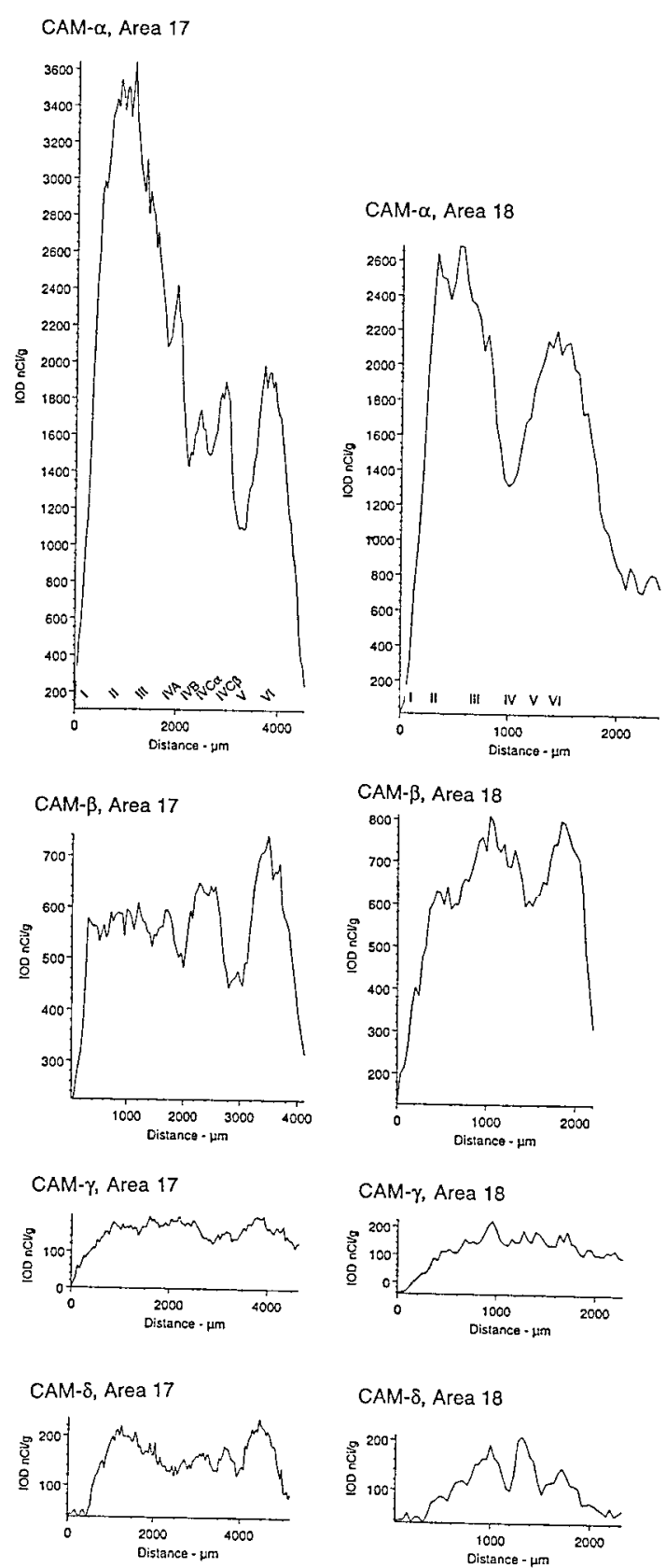

Figure 2. Integrated optical density readings (IOD) converted to measures of radioactivity ( $\mathrm{nCi} / \mathrm{gm})$ by reference to standards exposed on the same sheet of film and taken in traverses of constant width across the thickness of areas 17 and 18 in autoradiograms similar to those of Figure 1 but exposed for the same time on the same sheet of film. These reveal laminar patterns of expression as well as relative levels of expression of the four CaMKII isoforms. Note that the scales of the $y$ axes differ Roman numerals on the $x$ axes of the top graphs represent positions of cortical layers in all scans, as determined from optical density readings of adjacent Nissl-stained sections.

there was a thin line of label in the middle of layer V, corresponding to an interrupted line of labeled large cell somata.

Area 18. Labeling for CaMKII- $\gamma$ mRNA was extremely weak but showed a band of slightly enhanced hybridization corresponding to deep layer III (Fig. $3 F$ ) and a thin similarly enhanced band corresponding to layer VI (Fig. 1C). In deep layer III, many large neuronal somata were labeled.

\section{CaMKII- $\delta$}

Area 17. Labeling for CaMKII- $\delta$ mRNA showed a unique pattern of laminar distribution quite unlike that for the other three mRNAs (Fig. 1D). Layer VI, especially its superficial half, was labeled most densely. A band of relatively intense hybridization was found in layer II and superficial layer III. Layers IVC $\beta$ and IVA appeared as two bands of moderately dense labeling with large neuronal somata labeled in layer IVA (Fig. $3 G$ ). Labeling of layer IVC $\alpha$ was weak, although not quite as weak as that of layer IVB.

Area 18. There were very low levels of hybridization in area 18. Weakly enhanced bands of labeling corresponded to layers II and VI. Large cell somata were clearly labeled in deep layer III (Fig. $3 H)$.

\section{Laminar and cellular distribution of CaMKII immunostaining in normal visual cortex}

Immunocytochemistry for each of the four isoforms revealed staining densities comparable to those seen with in situ hybridization histochemistry. In some cases, especially for CaMKII- $\alpha$, bands of neuropil staining indicating stained axonal ramifications did not match the locations of cell somata labeled by cRNA probes.

For all four isoforms, by far the most prominent immunostained cells were pyramidal, but closer inspection revealed the presence of significant numbers of stained small, round neuronal somata as well, primarily in layer IV of each area. This reflected the staining of nonpyramidal cells, shown in a later section to be non-GABAergic. Although no counts were done, qualitatively only a subpopulation of pyramidal cells in any layer was labeled for CaMKII- $\alpha,-\beta,-\gamma$, or $-\delta$. This was also observed for CaMKII- $\alpha$ in the sensory-motor areas in which $<50 \%$ of the total cell population was labeled (Jones et al., 1994b).

\section{CaMKII- $\alpha$}

Immunoreactivity for CaMKII- $\alpha$ was similar to that briefly described by Hendry and Kennedy (1986). Staining was particularly dense in areas 17 and 18 and included both cell and neuropil staining (Fig. 5A,B). Many cells were stained in both areas (Fig. 6A-E).

Area 17. Cells were stained in all layers except layer I and the greater part of layer V. There were many stained cells in the white matter subjacent to layer VI. Neuropil staining did not always reflect cell staining patterns. For example, there was a dense neuropil band corresponding to layer $\mathrm{V}$. This probably reflected staining of collateral branches of the axons of pyramidal cells in supragranular layers, the collaterals of which contribute to the inner band of Baillarger (Lund et al., 1994). Other dense bands were coextensive with layers I and II, IVA, IVC $\beta$, and the deeper half of layer VI. Although at low magnification layer IV appeared weakly stained (Fig. 5A), there were many well-stained, small round cell somata in layers IVC $\alpha$ and IVC $\beta$, with fewer in layer IVB (Fig. 6A). Large cells, many of them pyramidal in shape, their stained apical dendrites giving layers IVC through VI a pattern of radial striping, were stained in layers III, IVA, and VI. Smaller pyramidal cells were stained in layers II and III.

Area 18. Immunostaining was also characterized by heavy staining of many cells except in layers I and V. The latter, as in area 17, was coextensive with a band of neuropil staining, although this was much weaker than was seen in area 17. Although containing fewer stained cells than other layers, layer $\mathrm{V}$ at intervals contained a number of very well-stained large pyramidal 

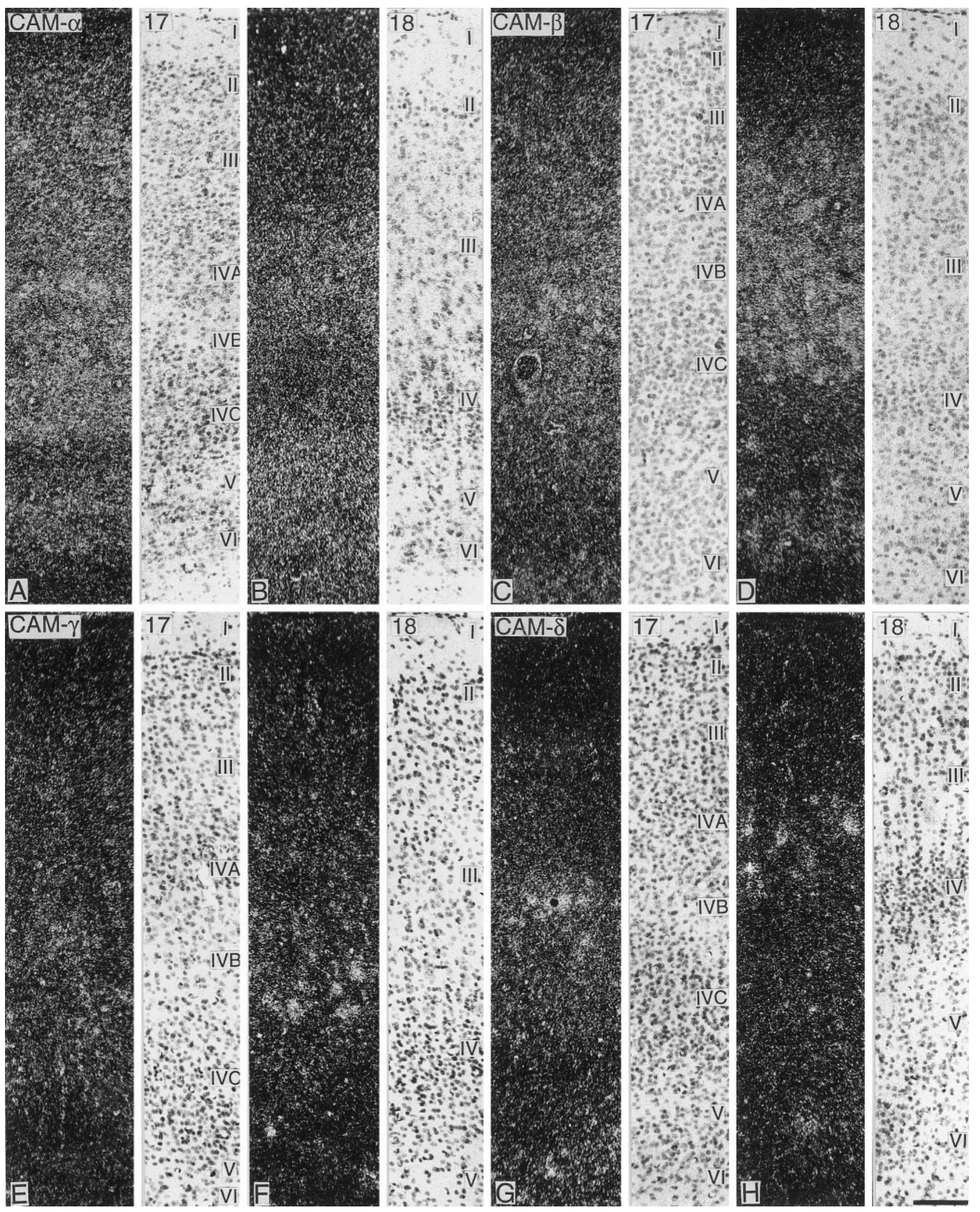

Figure 3. Pairs of dark-field (left) and bright-field (right) photomicrographs from the same counterstained emulsion autoradiograms showing relative densities and laminar patterns of expression of the four CaMKII mRNAs in areas $17(A, C, E, G)$ and $18(B, D, F, H)$. More diffuse labeling for CaMKII- $\alpha$, tending to obscure borders between layers at this magnification, reflects the high levels of the mRNA in dendrites of pyramidal cells (Benson et al., 1991a). Scale bar, $100 \mu \mathrm{m}$. 


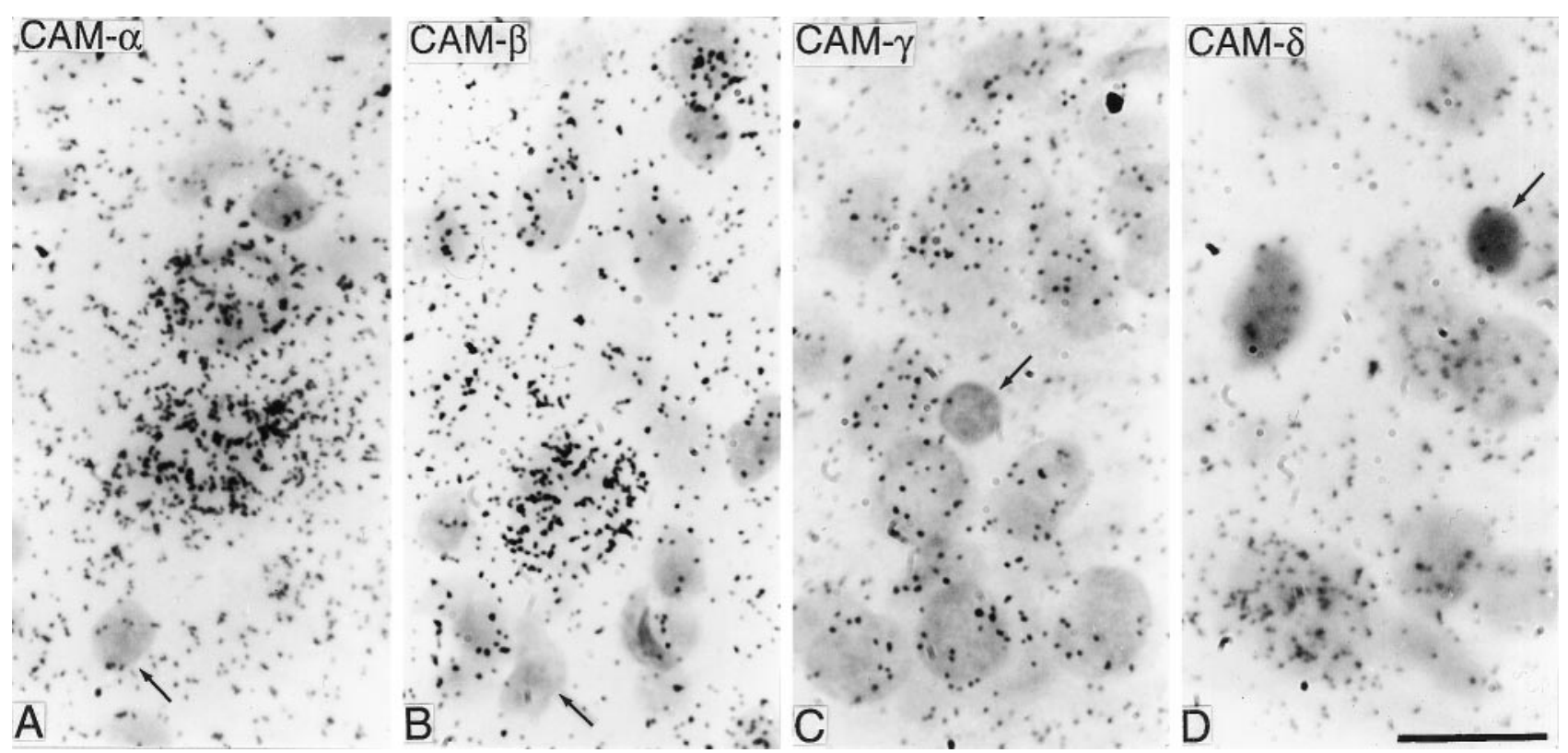

Figure 4. High-magnification photomicrographs from emulsion autoradiograms showing hybridization of cRNAs specific for each of the CaMKII mRNAs to neurons in layer VI of area $17(A)$, layer V of area $18(B)$, layer III of area $18(C)$, and layer VI of area $17(D)$. Arrows indicate nuclei of neuroglial cells which are not labeled. Scale bar, $10 \mu \mathrm{m}$.

cells. Pyramidal cells were also stained in layers II, III, and VI, and many small round neuronal somata were lightly stained in layer IV. There was dense staining of the neuropil in layers I and II.

\section{CaMKII- $\beta$}

Immunostaining for CaMKII- $\beta$ was also dense and included staining of many neuronal somata (Figs. 5C, 6F).

Area 17. There was denser neuropil staining in bands corresponding to layers IVA and IVC $\beta$. The band in layer IVA was broken at intervals in a manner similar to that seen with cytochrome oxidase staining of this layer. The band in layers IVC $\alpha$ and IVC $\beta$ contained many stained small cells. There were concentrations of well-stained larger cells in layers II, IVB, and upper VI. Fewer were found in layer V, and none in layer I. Many of the cells were pyramidal in shape with well-stained apical dendrites, giving the deeper layers a radially striped appearance. There were many stained cells in the superficial white matter.

Area 18. Immunostaining was relatively weak in layer IV (Figs. $5 D, 6 G)$. There were bands of enhanced neuropil staining in the upper part of layer V as well as in layers II and VI. There were many stained cells throughout all layers, except layer I, and in the superficial white matter. The staining of large pyramidal cells in deep layer III was especially prominent. Stained dendrites of pyramidal cells located in deeper layers gave the cortex a radially striped appearance.

\section{CaMKII- $\gamma$}

Area 17. Cells were clearly stained for CaMKII- $\gamma$, but neuropil staining was particularly weak (Fig. $5 E$ ), and the staining of cells was characterized by an unusual, fragmented appearance (Fig. $7 A$ ), the profiles of the stained cells not being continuous as was seen with CaMKII- $\alpha$ and CaMKII- $\beta$ immunostaining. The neuropil staining was weakest in layers I and IVB, although occasional stained cells were found in the latter. There were prominent bands of stained cells in layers IVB and IVC $\alpha$ and in the superficial half of layer VI. The smallest number of stained cells was in layer $\mathrm{V}$, although some very large, heavily stained cells occasionally appeared in its deepest aspect (Fig. $7 A$ ). The radial staining of the deeper layers found with CaMKII- $\alpha$ and CaMKII- $\beta$ immunostaining was absent. Many small cell somata were outlined by neuropil staining in layer IVC $\beta$, but the somata themselves lacked staining. No cells were stained in the white matter.

Area 18. Many pyramidal cells were stained against a background of relatively weak neuropil staining (Fig. $5 F$ ). There were scattered but well-stained pyramidal cells in layer V (Fig. 7B), and more weakly stained cells were found in all layers, except layer I, and in the superficial white matter.

\section{CaMKII- $\delta$}

Immunoreactivity for CaMKII- $\delta$ was weakest of the four isoforms, but staining of neuronal somata was more distinct than for CaMKII- $\gamma$. Many neuronal somata were stained in both areas, including the superficial white matter. Many were pyramidal in shape, but small round somata were also stained in layer IVC of area 17 . There were also a few rather well-stained larger pyramidal cells in deep layer $\mathrm{V}$ of both areas (Fig. 7C,D), and there was an enhancement of neuropil staining in bands in both areas 17 and 18 (Figs. 5G, $H, 7 C, D$ ).

Area 17. Bands corresponded to layers IVA and IVB, the middle of layer V, and layer VI. There was very weak staining of layers I through III.

Area 18. Neuropil staining was even weaker in area 18 than in area 17, although there was enhancement in deep layer III and in layer VI (Fig. 5H). Layers I and IV were weakest of all.

\section{Colocalization of CaMKII- $\alpha$ and CaMKII- $\beta$ in non-GABA cells}

Immunofluorescent staining revealed localization of CaMKII- $\alpha$ and CaMKII- $\beta$ in pyramidal cells (Fig. $8 A-D$ ) of all layers of areas 17 and 18, as well as in small round cells (Fig. $8 A, C$ ) of layer 


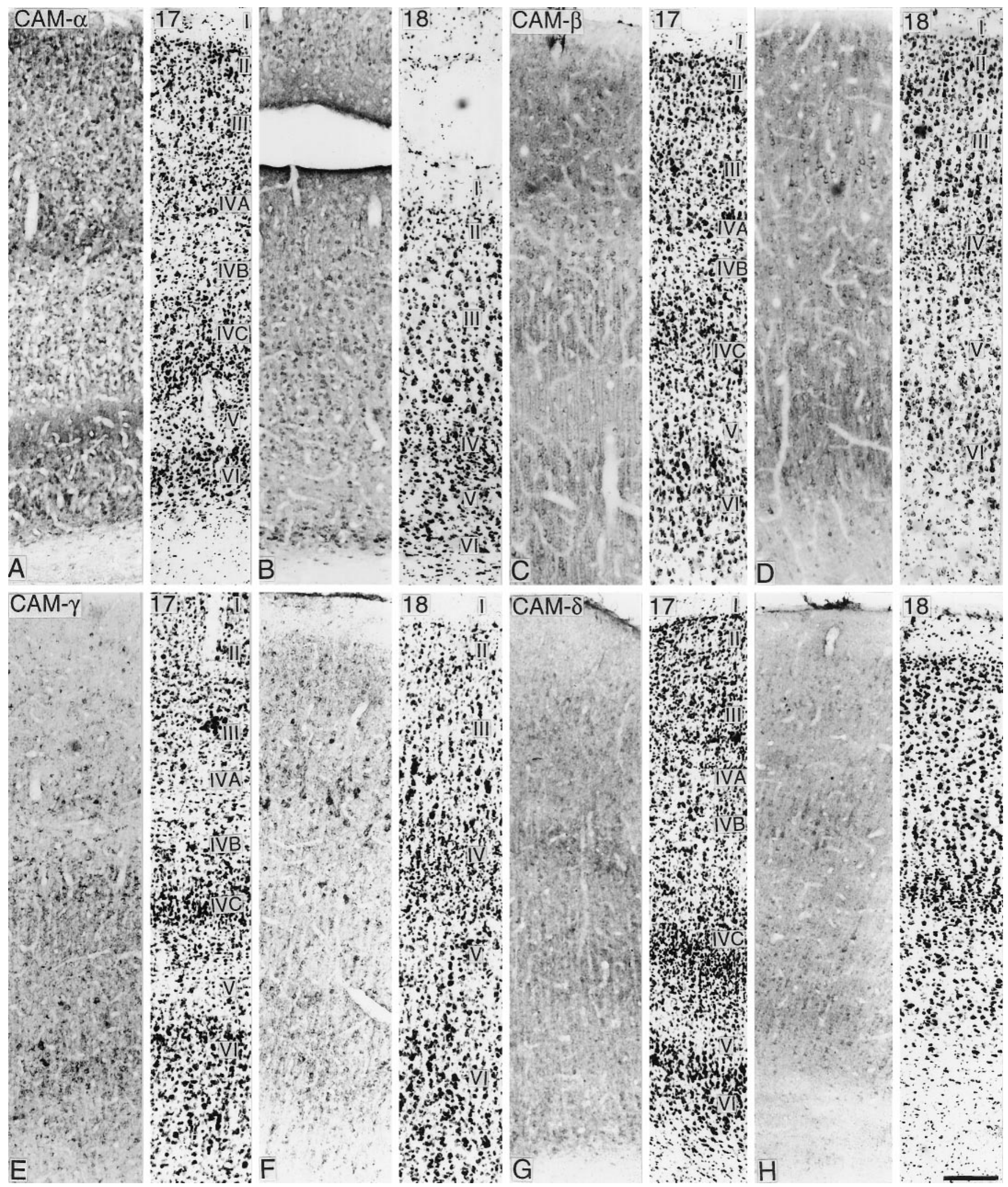

Figure 5. Photomicrographs from pairs of adjacent sections stained immunocytochemically $(l e f t)$ for one of the four CaMKII isoforms or with thionin (right) and showing the laminar patterns of immunostaining in areas $17(A, C, E, G)$ and $18(B, D, F, H)$. Dense neuropil staining in the absence of somal staining (e.g., layers IVA and V of area 17) reflects immunostaining of axons and dendrites. Scale bar, $100 \mu \mathrm{m}$. 


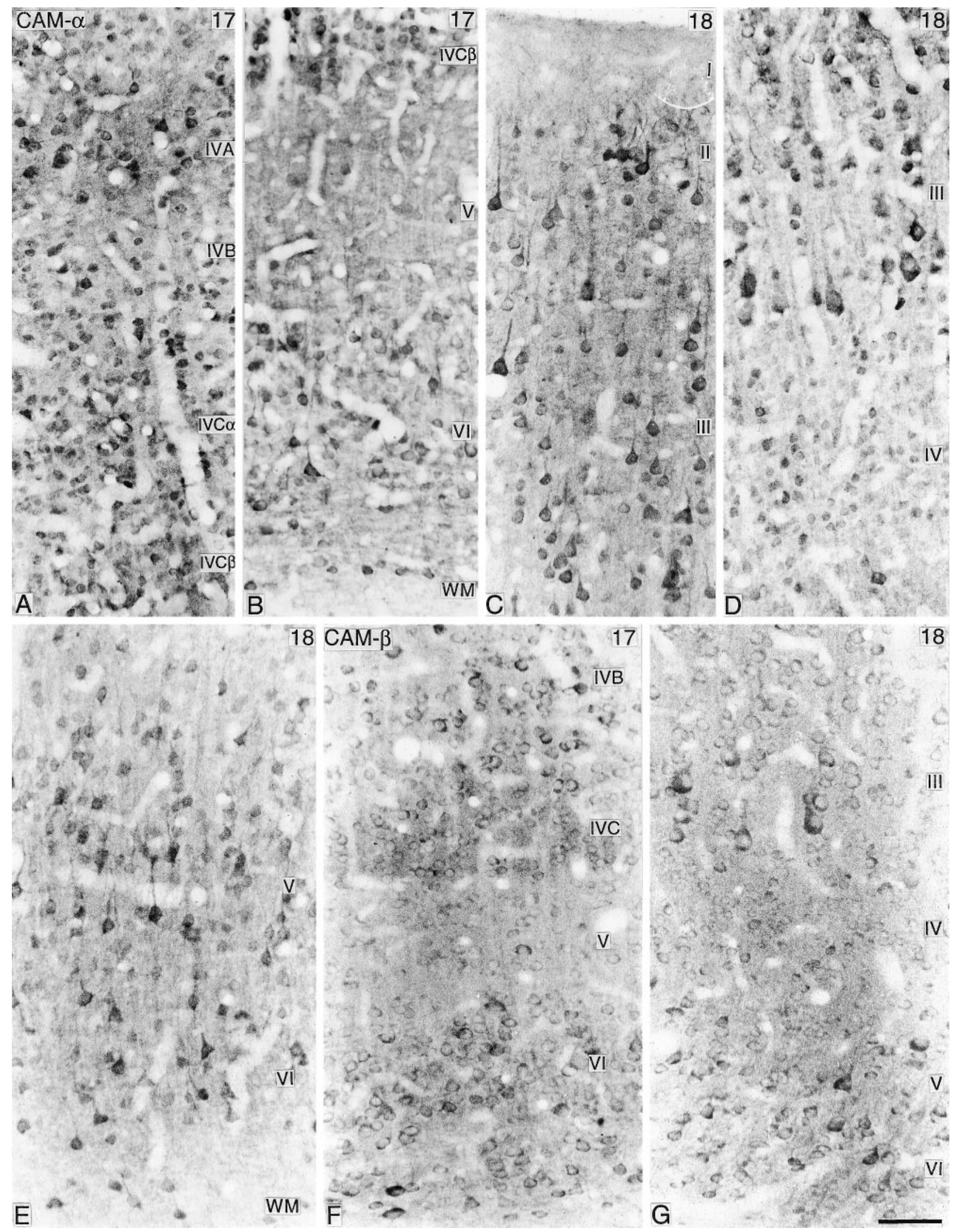

Figure 6. High-magnification photomicrographs showing immunostaining of cells in different layers of areas 17 or 18 for CaMKII- $\alpha(A-E)$ or CaMKII- $\beta(F, G)$. (These are different sections from those shown in Fig. 5.) Note the staining of pyramidal cells in all layers and the staining of small round cell somata in layers IVC (area 17) and IV (area 18). WM, White matter. Scale bar, $150 \mu \mathrm{m}$. 


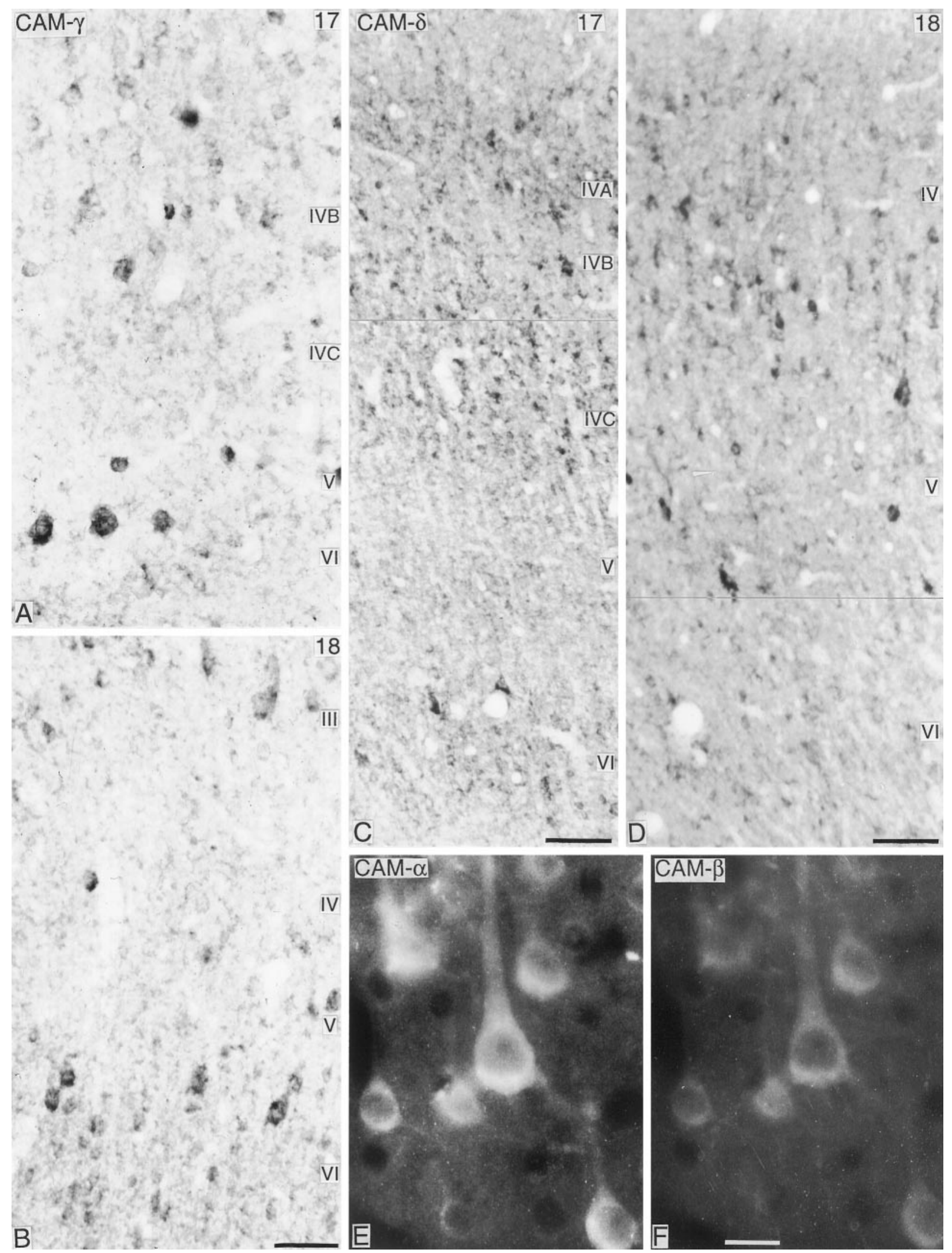

Figure 7. $A-D$, Bright-field photomicrographs showing immunostaining of cells for CaMKII- $\gamma$ or CaMKII- $\delta$ in deeper layers of areas 17 and 18 . The isolated large neuronal somata stained in layer $\mathrm{V}$ of area 17 are those of Meynert cells. Scale bars, $150 \mu \mathrm{m}$. $E, F$, Fluorescence micrographs from the same microscopic field showing double staining of cells in layer III of area 17 for CaMKII- $\alpha$ ( $E$, rhodamine immunofluorescence) and CaMKII- $\beta$ ( $F$, fluorescein immunofluorescence). Scale bar, $10 \mu \mathrm{m}$. 

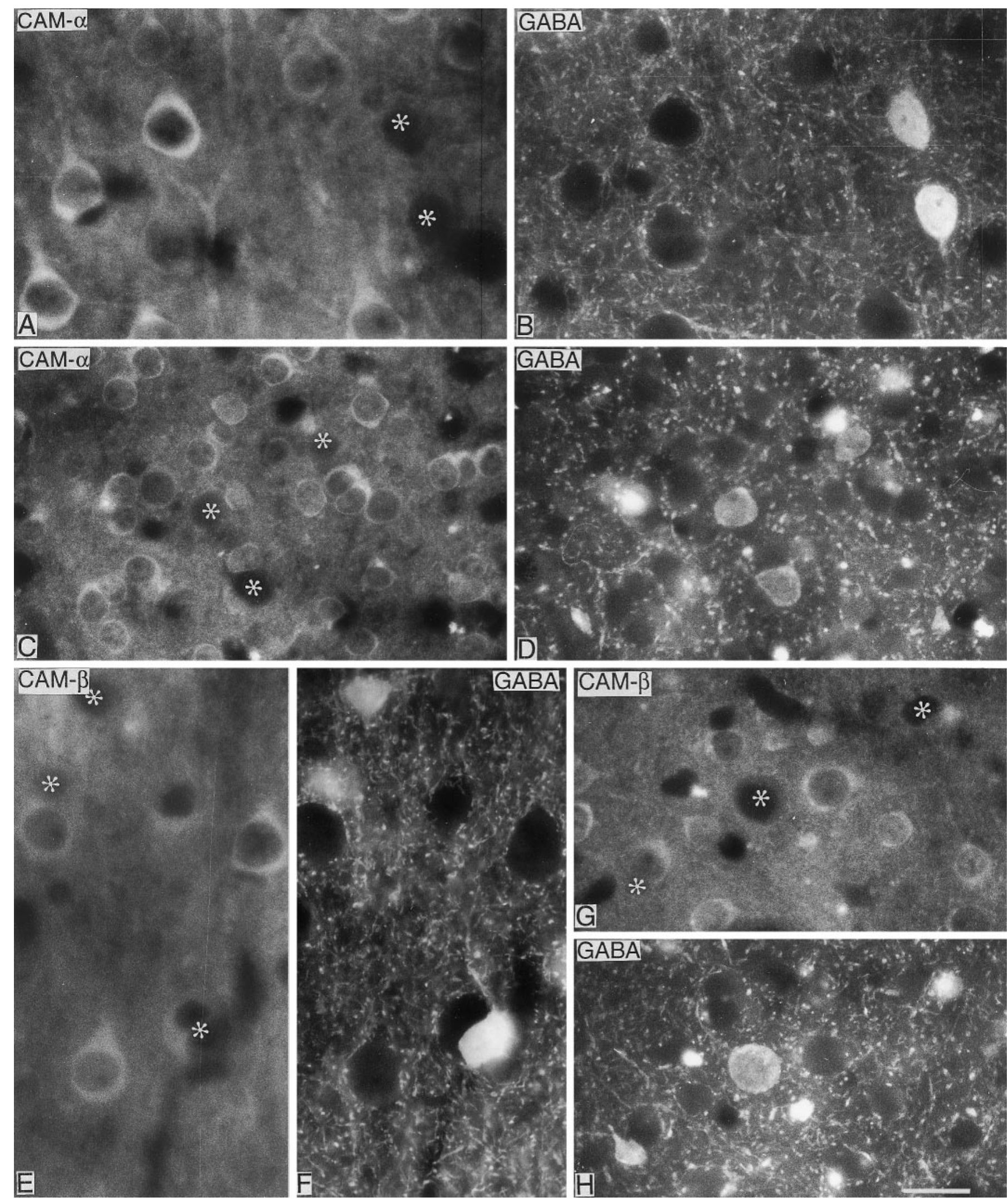

Figure 8. Paired fluorescence photomicrographs from the same microscopic fields stained for CaMKII- $\alpha(C A M-\alpha)$ and GABA $(A-D)$ or for CaMKII- $\beta(C A M-\beta)$ and GABA $(E-H)$. $A, B, E, F$, From layer III of area 17 and showing CaMKII- $\alpha$ and $-\beta$ immunoreactivity in pyramidal cells but not in GABA cells. $C, D, G, H$, From layer IVC $\beta$ of area 17 and showing CaMKII- $\alpha$ and - $\beta$ immunoreactivity in small, presumably spiny stellate cells and not in GABA cells. In the CaMKII- $\alpha$ - or CaMKII- $\beta$-immunostained member of each pair of micrographs, the unstained GABA cells are indicated by asterisks. Scale bar, $10 \mu \mathrm{m}$. 

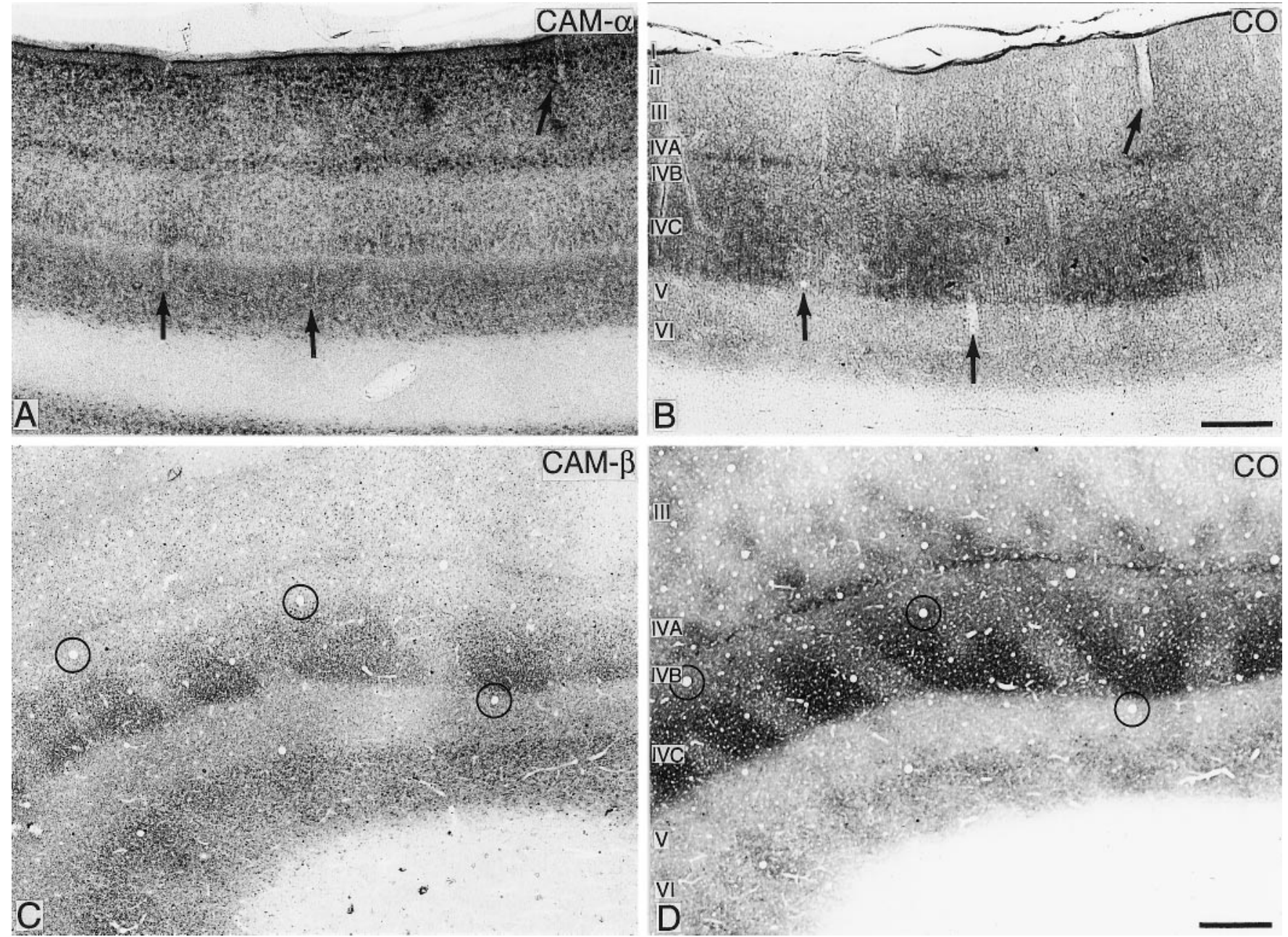

Figure 9. Pairs $(A, B ; C, D)$ of adjacent sections from area 17 stained immunocytochemically for CaMKII- $\alpha(A)$ or CaMKII- $\beta(C)$ or for CO $(B, D)$. Sections are from a $M$. fascicularis $(A, B)$ and a $M$. fuscata $(C, D)$ monkey subjected to monocular TTX injections for $7 \mathrm{~d}$. Zones of reduced CO staining in layer IVC represent ocular dominance columns related to the deprived eye. CaMKII- $\alpha$ immunostaining is enhanced and CaMKII- $\beta$ immunostaining is reduced in regions corresponding to the deprived columns, especially in layer IVC $\beta$. Arrows in $A$ and $B$ and circles in $C$ and $D$ indicate the same blood vessels. Scale bars: $A, B, 250 \mu \mathrm{m} ; C, D, 500 \mu \mathrm{m}$.

IVC in area 17 and of layer IV in area 18. No CaMKII- $\alpha$ - or CaMKII- $\beta$-immunoreactive neuron showed colocalization of GABA immunoreactivity (Fig. $8 A-D$ ) in any layer or in the subcortical white matter. In layer IVC of area 17 or layer IV of area 18, small round CaMKII-immunoreactive somata were significantly smaller in diameter than were the largest GABAimmunoreactive somata, as reported previously (Jones et al., 1994a,b).

Double immunofluorescent staining for CaMKII- $\alpha$ and CaMKII- $\beta$ showed virtually complete colocalization (Fig. $7 E, F$ ) of the two isoforms in all layers of both areas, including in the interstitial cells of the white matter.

It was not possible to obtain satisfactory double staining using the CaMKII- $\gamma$ or CaMKII- $\delta$ antibodies, because of the low levels of these antigens.

\section{Response to monocular deprivation}

In area 17, both immunoreactivity and mRNA levels for CaMKII- $\alpha$ and CaMKII- $\beta$ were affected by monocular deprivation induced by TTX injections (Figs. 9-11). No changes were detected for CaMKII- $\delta$, and CaMKII- $\gamma$ showed inconsistent equivocal changes (Fig. 12). For CaMKII- $\alpha$ and CaMKII- $\beta$, effects were most pronounced in layer IVC $\beta$. The pattern of localization, from its normal homogeneity in that layer, became one of alternating lightly and densely immunostained or cRNAlabeled stripes (Figs. 9, 10). Comparison with adjacent sections stained for $\mathrm{CO}$ showed that unilateral deprivation induced opposite effects on CaMKII- $\alpha$ and CaMKII- $\beta$. For CaMKII- $\alpha$, the darkly immunostained or more intensely hybridized stripes were almost exactly coextensive with lightly $\mathrm{CO}$-stained stripes that corresponded to the deprived eye, and the lightly immunostained or hybridized stripes were coextensive with the darkly COstained stripes corresponding to the undeprived eye. In all cases, the denser immunostained or hybridized stripes were more intensely labeled in layer IVC $\beta$ then in layer IVC $\alpha$ of the deprived ocular dominance stripes. For CaMKII- $\beta$, lightly immunostained or hybridized stripes in layer IVC $\beta$ corresponded to deprived ocular dominance stripes when matched to the adjacent, $\mathrm{CO}$ stained sections (Fig. 11) but mainly to the central parts of the deprived stripes. There were hints of a deprivation effect in striped immunostaining in layer VI for CaMKII- $\beta$.

Optical density measurements indicated that there was an enhancement of CaMKII- $\alpha$ mRNA by $\sim 30 \%$ in deprived ocular 

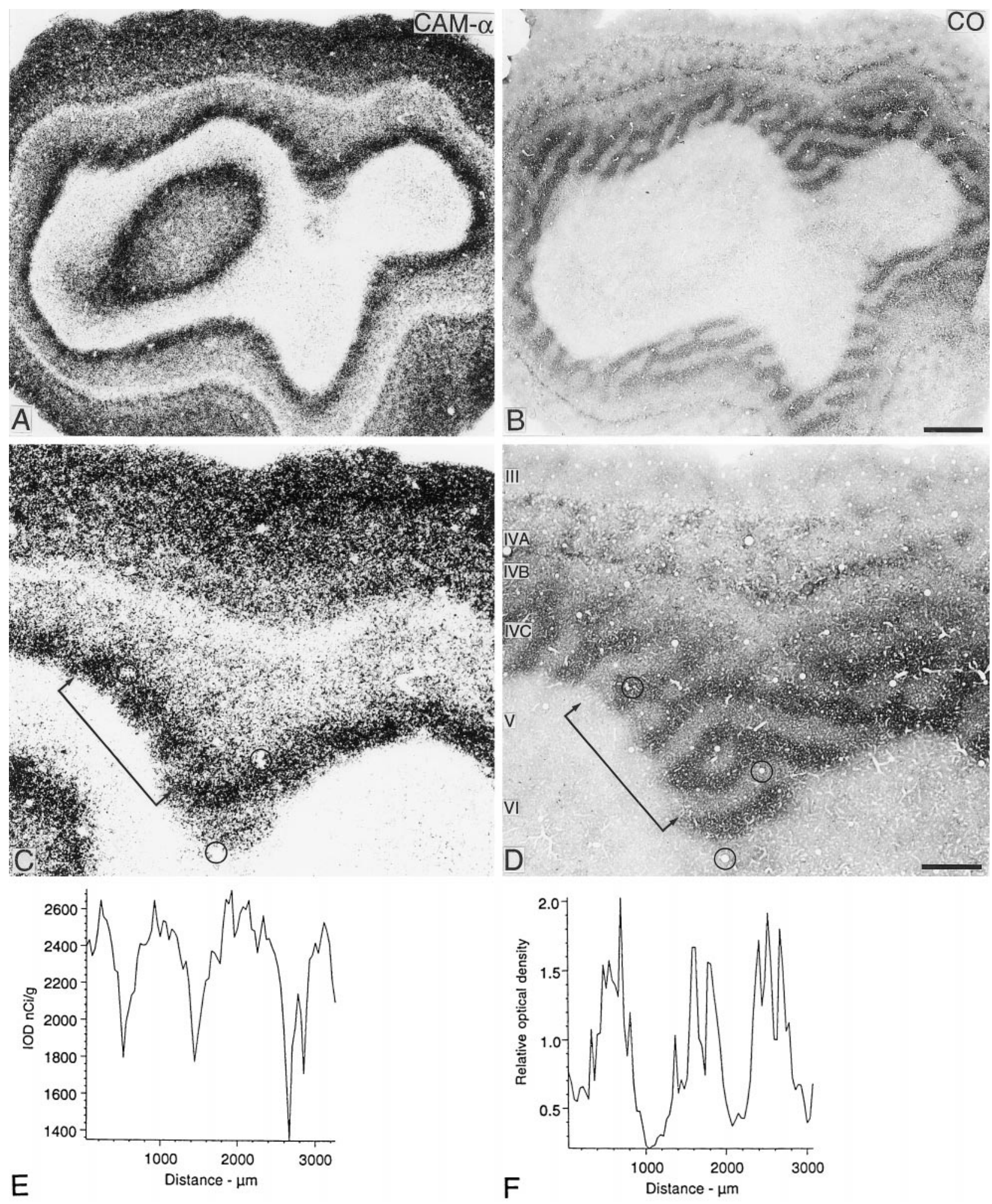

Figure 10. A, Autoradiogram from a surface parallel section through area 17 of a $M$. fuscata monkey monocularly deprived for 7 d. The section was hybridized with a CaMKII- $\alpha$ riboprobe. $B$, An adjacent section stained for CO. $C, D$, Enlargements of upper parts of $A$ and $B$. Circles indicate the same blood vessels. Scale bars: $A, B, 2 \mathrm{~mm} ; C, D, 1 \mathrm{~mm}$. $E, F$, Optical density scans made across layer IVC in regions indicated by the lines between the arrows in $C$ and $D$ converted to measures of radioactivity to show enhancement of CaMKII- $\alpha$ mRNA levels in deprived ocular dominance columns, the positions of which can be determined by matching to the zones showing reduced CO staining and lowered optical density. 


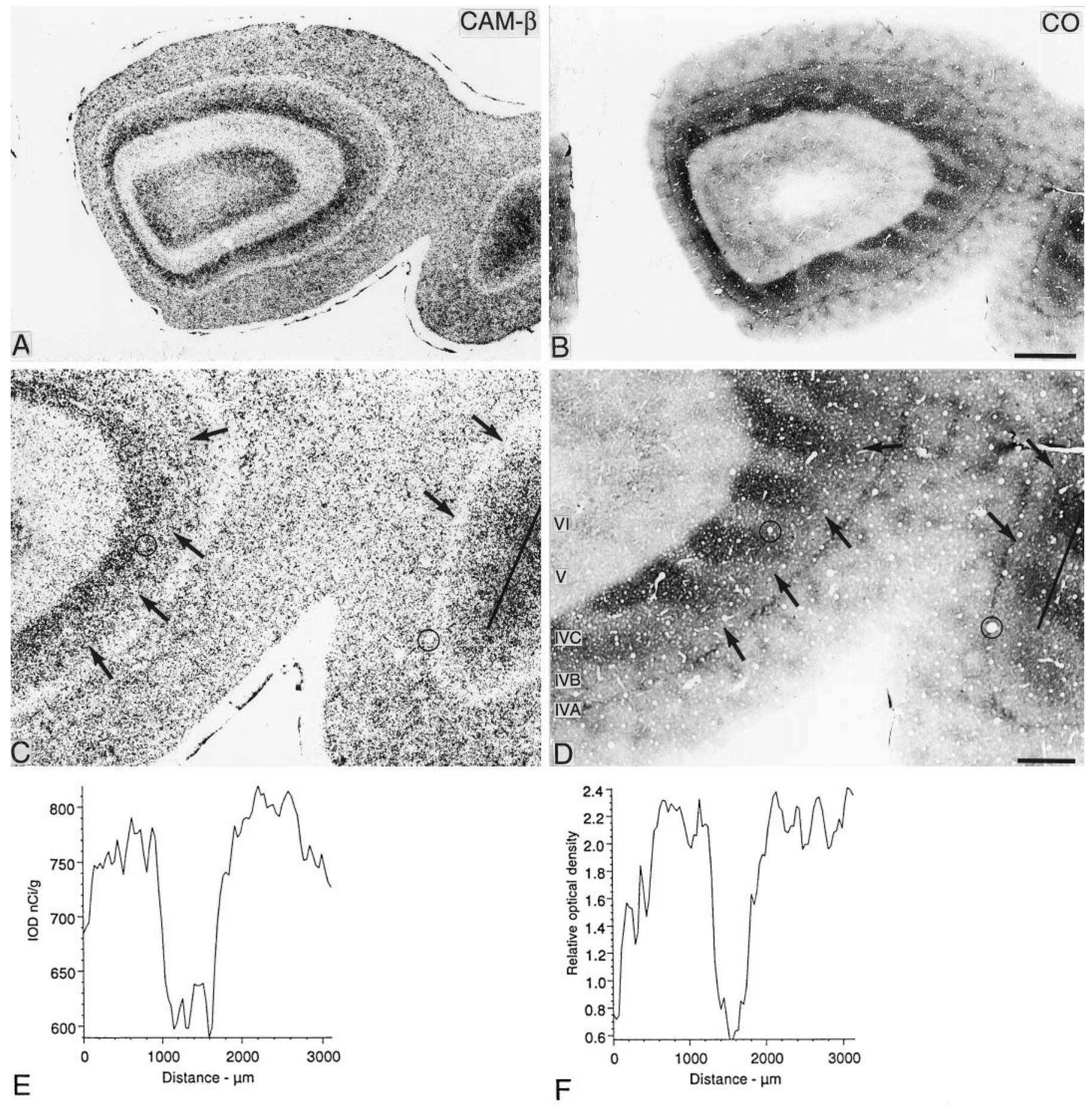

Figure 11. A, Autoradiogram from a surface parallel section through area 17 of a $M$. fuscata monkey monocularly deprived for $16 \mathrm{~d}$. The section was hybridized with a CaMKII- $\beta$ riboprobe. $B$, An adjacent section stained for CO. $C, D$, Enlargements of middle regions of $A$ and $B$. Circles indicate the same blood vessels, and arrows indicate the same deprived ocular dominance columns in layer IVC. $E, F$, Optical density scans made along the lines indicated in $C$ and $D$ and showing decreased CaMKII- $\beta$ mRNA levels in the deprived ocular dominance columns. Scale bars: $A, B, 2 \mathrm{~mm} ; C, D, 500 \mu \mathrm{m}$.

dominance stripes of layer IVC $\beta$ (Fig. 10E,F) and a decrease of CaMKII- $\beta$ mRNA of $\sim 25 \%$ (Fig. $11 E, F$ ). No changes in the distribution or density of mRNA labeling could be detected in layers other than layer IVC. The CO-rich blobs of layers II and III appeared unaffected. No changes were detected in area 18. No quantitative changes could be detected in CaMKII- $\gamma$ or $-\delta$ mRNAs.

\section{DISCUSSION}

\section{CaMKII and neuron-specific expression}

Expression of CaMKII- $\alpha$, $-\beta$, and $-\delta$ isoforms was exclusively neuronal. CaMKII- $\gamma$ is also neuronal, but its additional expression in neuroglial cells could not be excluded because of very low levels of CaMKII- $\gamma$ mRNA and protein. For all four isoforms, 


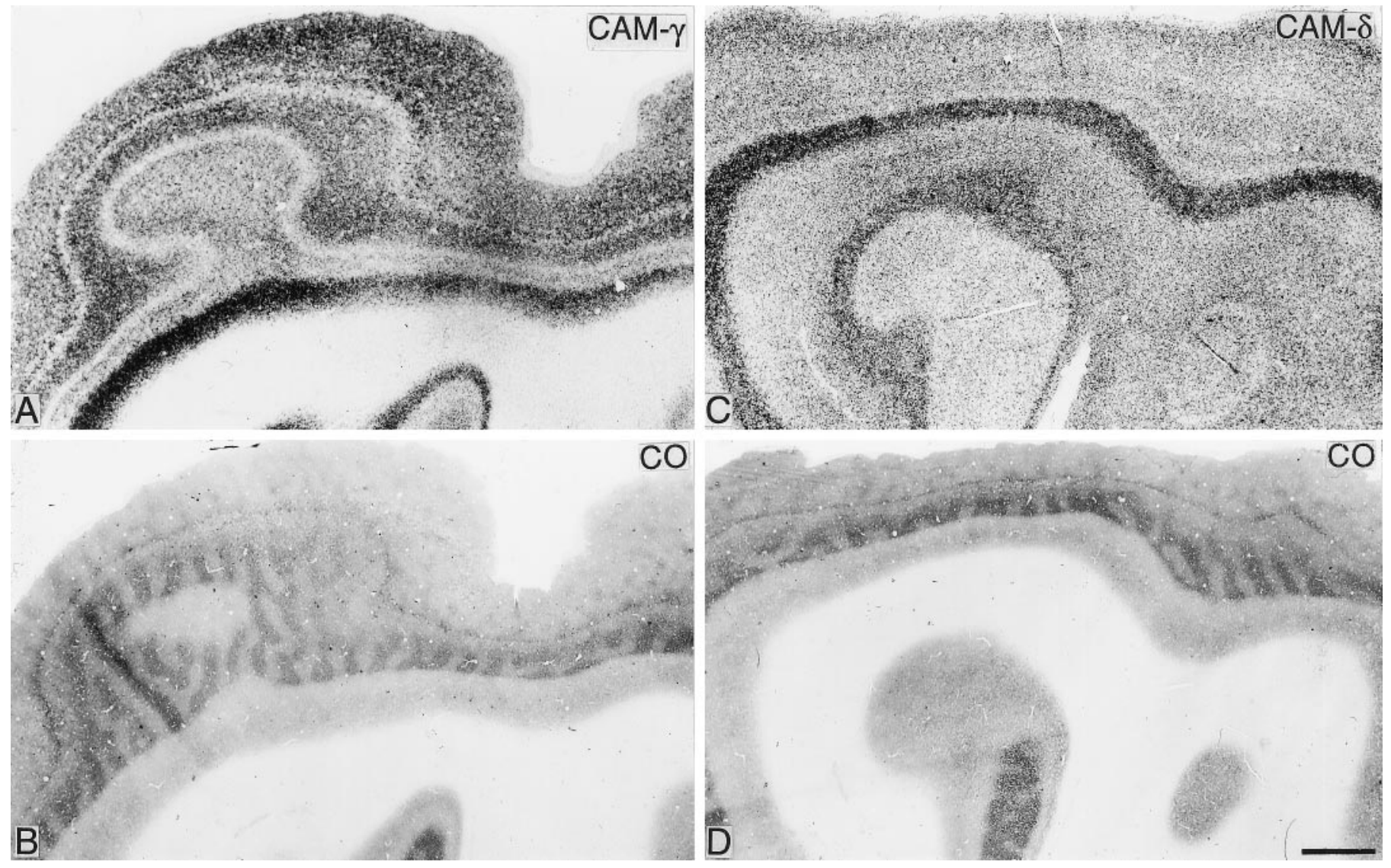

Figure 12. A, C, Autoradiograms of sections through area 17 of a $M$. fuscata monkey monocularly deprived for $7 \mathrm{~d}$. $A$, Section hybridized to a CaM KII- $\gamma$ riboprobe. $C$, Section hybridized to a CaMKII- $\delta$ riboprobe. Sections have been exposed for $15 \mathrm{~d} . B, D$, The adjacent CO-stained sections. No deprivation effect can be detected for either mRNA. Scale bar, $2 \mathrm{~mm}$.

pyramidal cells are the predominant expressing cell, but CaMKII- $\alpha$ and CaMKII- $\beta$ and probably CaMKII- $\gamma$ and $-\delta$ are expressed in nonpyramidal cells as well, especially in layer IVC of area 17 and in layer IV of area 18. Although CaMKII- $\alpha$ is expressed at much higher levels overall than is CaMKII- $\beta$, the in situ pattern suggests that layer IVC cells may express CaMKII- $\beta$ at higher levels relative to pyramidal cells of layers II-III than CaMKII- $\alpha$ (Fig. 1).

Nonpyramidal cells expressing CaMKII- $\alpha$ or $-\beta$ were nonGABAergic. This and laminar localization suggest expression in spiny stellate cells, the second major form of cortical excitatory cell. Interstitial cells of the white matter labeled for CaMKII- $\alpha$, $-\beta$, and $-\delta$ are another form of non-GABAergic, nonpyramidal cell. It could not be proven conclusively, because of low immunostaining levels, that CaMKII- $\gamma$ and $-\delta$ are also expressed only in pyramidal and non-GABAergic nonpyramidal cells. Because CaMKII- $\gamma$ and $-\delta$, unlike CaMKII- $\alpha$ and $-\beta$, are expressed in many tissues outside the nervous system, the possibility of their less-restricted neuronal expression should be considered.

Relative laminar densities of hybridization in areas 17 and 18 varied for each isoform, but for all, the major pyramidal cell populations labeled were in layers II-III, IVA (in area 17), and VI. Smaller numbers of large pyramidal cells in deep layer V and of modified pyramidal cells in layer IVB of area 17 were also labeled for all isoforms. This may indicate that a very specific subpopulation of pyramidal cells expresses the CaMKII isoforms. A similar staining pattern occurs with other markers, e.g., nonphosphorylated neurofilament protein (Hof and Morrison, 1995, Hof et al., 1995), and seems to reflect staining of pyramidal cells with particular connectional relationships. This may be the most likely relevance of the preferential labeling of the pyramidal cell subpopulations in the present study (see below). However, strong activity-dependent regulation of CaMKII- $\alpha$ (Bronstein et al., 1992; Liang et al., 1996; Liang and Jones, 1997; see below) raises the possibility of an activity-dependent effect. Compensation for lack of expression of one isoform by upregulation of another seems unlikely from the consistency of the subpopulation labeled for each isoform and by the almost complete coexpression of CaMKII- $\alpha$ and $-\beta$ that may imply formation of heteromeric combinations of the two.

\section{CaMKII and cortical connectivity}

High levels of expression of CaMKII- $\alpha$ in supragranular pyramidal cells-the sources of the majority of corticocortical and commissural fibers (for review, see Casagrande and Kaas, 1994)imply that cortical plasticity dependent on CaMKII- $\alpha$ will be reflected directly onto other areas of the cortex. In area 17, consistent expression of all four isoforms in layer IVA implies association with the large pyramidal cells that project selectively to cytochrome oxidase-stained thick stripes of layer III in area 18 (Livingstone and Hubel, 1987a; Levitt et al., 1994), part of a pathway dominated by inputs from broad-band-sensitive cells of the magnocellular layers in the dorsal lateral geniculate nucleus (Livingstone and Hubel, 1987b, 1988). High levels of expression 
in layer VI cells from which the majority of corticothalamic projections arise and the particular association of CaMKII- $\alpha$ with corticothalamic synapses (Liu and Jones, 1996) imply that the thalamus will also be influenced. Higher expression in upper layer VI, from which fibers to the parvocellular geniculate layers arise (Lund et al., 1975), suggests a particular association with those layers.

The relative absence of expression of all four isoforms in layer $\mathrm{V}$ was a striking feature, but equally striking was the intense immunostaining of a few large pyramidal cells and a corresponding thin line of mRNA labeling in the middle or deep aspect of that layer, especially for CaMKII- $\beta,-\gamma$, and $-\delta$. The large pyramidal cells are likely to be cells the axons of which descend to the pulvinar, pretectum, and tectum (Lund et al., 1975; Trojanowski and Jacobson, 1976), but they may also represent Meynert cells with projections to extrastriate cortical fields (Fries et al., 1985).

There was no particular correlation between enhanced expression in layers or sublayers of area 17 and that in laminae of the dorsal lateral geniculate nucleus projecting to those layers. In the lateral geniculate nucleus, CaMKII- $\alpha$ is specifically expressed in neurons of the $\mathrm{S}$ laminae and interlaminar zones (Benson et al., 1991b; Tighilet et al., 1998) that project to superficial layers of areas 17 and 18, including the CO-rich blobs of area 17 (Yukie and Iwai, 1981; Livingstone and Hubel, 1982; Fitzpatrick et al., 1983; Weber et al., 1983; Hendry and Yoshioka, 1994). Blobs in area 17 are enriched in CaMKII- $\alpha$ but to no greater extent than the rest of layers II-III. The other three isoforms are expressed in relay cells of the parvo- and magnocellular laminae of the lateral geniculate nucleus, as well as in the S laminae and interlaminar zones (Tighilet et al., 1998). The parvocellular laminae project to layers IVA and IVC $\beta$ of area 17, whereas the magnocellular layers project to layer IVC $\alpha$ (Hubel and Wiesel, 1972; Blasdel and Lund, 1983). CaMKII- $\alpha$ and $-\gamma$ are enriched in layers IVA and IVC $\beta$, whereas CaMKII- $\beta$ and $-\alpha$ are enriched in layers IVA, IVC $\alpha$, and IVC $\beta$. There is no obvious correlation here, except that parvocellular geniculate cells gain access to cells enriched for CaMKII- $\alpha,-\beta,-\gamma$, and $-\delta$, whereas magnocellular geniculate cells gain access primarily to cells enriched for CaMKII- $\beta$ and $-\gamma$.

\section{CaMKII and cortical plasticity}

Upregulation of CaMKII- $\alpha$ expression in deprived ocular dominance columns of layer IVC in area 17 confirmed previous reports at protein (Hendry and Kennedy, 1986) and mRNA (Benson et al., 1991a) levels. The equally striking downregulation of CaMKII- $\beta$ in the same columns is a new finding. Both effects are considerable; at the mRNA level, deprived columns change by $\sim 30 \%$ in each case. The most robust effects were on layer IVC $\beta$, implying that the major group of recipient cells in the wavelengthspecific thalamocortical pathway is most affected in the cortex.

CaMKII- $\alpha$ is involved in induction of LTP at hippocampal synapses (Malenka et al., 1989; Malinow et al., 1989) and in experience-dependent plasticity of adult somatosensory cortex (Glazewski et al., 1996). In visual cortex, it is essential for induction of LTP in supragranular layers of adult but not infant animals (Kirkwood et al., 1997) and is partially involved in ocular dominance plasticity of the same layers during the neonatal critical period (Gordon et al., 1996). In these layers, CaMKII- $\alpha$ is highly expressed, but only in the non-GABAergic pyramidal cells (Jones et al., 1994b; present study). In these cells, it is concentrated at postsynaptic densities of glutamatergic synapses (Liu and Jones, 1996), undoubtedly reflecting the association of CaMKII- $\alpha$ and NMDA receptors in cortical LTP (Artola and Singer, 1987).
Despite the involvement of CaMKII- $\alpha$ in adult, experiencedependent plasticity at these synapses, monocular deprivation in the present study did not affect CaMKII- $\alpha$ gene expression in layers II-III. This is surprising, given that deprivation for the same period results in effects on GABA, GAD, tachykinin, and $\mathrm{GABA}_{\mathrm{A}}$ receptor gene expression in layers II-III that parallel those in layer IVC, especially in the CO-rich blobs (Hendry and Jones, 1986; Hendry et al., 1988, 1994; Benson et al., 1994; Huntsman et al., 1994). Induction of LTP in supragranular neurons of cat and rat visual cortex by stimulation of afferent fibers depends on reduction of intracortical inhibition (e.g., Artola et al., 1990; Bear et al., 1992; Tsumoto, 1992), but LTP can be induced without disinhibition if layer IV is stimulated directly (Kirkwood and Bear, 1994). This implies that layer IV may normally exert a gating effect over afferent-induced plasticity in the supragranular layers.

In the present study, inhibition should be reduced in the deprived ocular dominance columns because GABA production and $\mathrm{GABA}_{\mathrm{A}}$ receptors will be markedly downregulated in layer IVC (see above). The complementary effects on CaMKII- $\alpha$ and - $\beta$ may therefore be part of a response to restore the balance of excitation and inhibition to layer IV, serving to protect the supragranular layers from the consequences of deprivation in adults. Upregulation of CaMKII- $\alpha$ can be seen as an attempt to compensate for reduced input by engaging cellular mechanisms that should enhance excitatory transmission. This could be a key feature in protecting the cortex from the consequences of deprivation. By also engaging intracellular mechanisms that inhibit neuronal growth, the upregulated CaMKII- $\alpha$ could limit potential sprouting that would be maladaptive. Until more is known about CaMKII- $\beta$, it is difficult to predict the extent to which downregulation of this isoform also represents a compensatory response in the same cells. This would be likely if the two isoforms, shown here to be colocalized, normally form heteromers in layer IVC cells. There is, however, increasing evidence of differential intracellular localization and trafficking of CaMKII- $\alpha$ isoforms (Brocke et al., 1995). In this case, the opposite effects on CaMKII- $\alpha$ and $\beta$ and the lack of effects on CaMKII- $\gamma$ or $\delta$ may reflect responses of entirely different intracellular signaling systems.

\section{REFERENCES}

Artola A, Singer W (1987) Long-term potentiation and NMDA receptors in rat visual cortex. Nature 330:649-652.

Artola A, Brocher S, Singer W (1990) Different voltage-dependent thresholds for inducing long-term depression and long-term potentiation in slices of rat visual cortex. Nature 347:69-72.

Bear MF, Press WA, Connors BW (1992) Long-term potentiation in slices of kitten visual cortex and the effects of NMDA receptor blockade. J Neurophysiol 67:841-851.

Bennett MK, Kennedy MB (1987) Deduced primary structure of the $\beta$ subunit of brain type II $\mathrm{Ca} 2+/$ calmodulin-dependent protein kinase determined by molecular cloning. Proc Natl Acad Sci USA 84:1794-1798.

Bennett MK, Erondu NE, Kennedy MB (1983) Purification and characterization of a calmodulin-dependent protein kinase that is highly concentrated in brain. J Biol Chem 258:12735-12744.

Benson DL, Isackson PJ, Gall CM, Jones EG (1991a) Differential effects of monocular deprivation on glutamic acid decarboxylase and type II calcium-calmodulin-dependent protein kinase gene expression in the adult monkey visual cortex. J Neurosci 11:31-47.

Benson DL, Isackson PJ, Hendry SHC, Jones EG (1991b) Differential gene expression for glutamic acid decarboxylase and type II calciumcalmodulin-dependent protein kinase in basal ganglia, thalamus, and hypothalamus of the monkey. J Neurosci 11:1540-1564.

Benson DL, Isackson PJ, Gall CM, Jones EG (1992) Contrasting pat- 
terns in the localization of glutamic acid decarboxylase and $\mathrm{Ca} 2+/$ calmodulin protein kinase gene expression in the rat central nervous system. Neuroscience 46:825-850.

Benson DL, Huntsman MM, Jones EG (1994) Activity-dependent changes in GAD and preprotachykinin mRNAs in visual cortex of adult monkeys. Cereb Cortex 4:40-51.

Blasdel GG, Lund JS (1983) Termination of afferent axons in macaque striate cortex. J Neurosci 3:1389-1413.

Braun AP, Schulman H (1995) The multifunctional calcium/ calmodulin-dependent protein kinase: from form to function. Annu Rev Neurosci 57:417-445.

Brocke L, Srinivasan M, Schulman H (1995) Developmental and regional expression of multifunctional $\mathrm{Ca}^{2+} /$ calmodulin-dependent protein kinase isoforms in rat brain. J Neurosci 15:6797-6808.

Bronstein JM, Micevych P, Popper P, Huez G, Farber DB, Wasterlain CG (1992) Long-lasting decreases of type II calmodulin kinase expression in kindled rat brains. Brain Res 584:257-260.

Burgin KE, Waxham MN, Rickling S, Westgate SA, Mobley WC, Kelly PT (1990) In situ hybridization histochemistry of $\mathrm{Ca}^{2+} /$ calmodulindependent protein kinase in developing rat brain. $\mathrm{J}$ Neurosci 10:1788-1798.

Casagrande VA, Kaas JH (1994) The afferent, intrinsic, and efferent connections of primary visual cortex in primates. In: Cerebral cortex, Vol 10, Primary visual cortex in primates (Peters A, Rockland K, eds), pp 201-260. New York: Plenum.

Edman CF, Schulman H (1994) Identification and characterization of delta B-CaM kinase and delta C-CaM kinase from rat heart, two new multifunctional $\mathrm{Ca} 2+/$ calmodulin-dependent protein kinase isoforms. Biochim Biophys Acta 1221:89-101.

Erondu NE, Kennedy MB (1985) Regional distribution of type II $\mathrm{Ca}^{2+}$ / calmodulin-dependent protein kinase in rat brain. $\mathrm{J}$ Neurosci 5:3270-3277.

Fitzpatrick D, Itoh K, Diamond IT (1983) The laminar organization of the lateral geniculate body and the striate cortex in the squirrel monkey (Saimiri sciureus). J Neurosci 3:673-702.

Fries W, Keizer K, Kuypers HGJM (1985) Large layer VI cells in macaque striate cortex (Meynert cells) project to both superior colliculus and prestriate visual area V5. Exp Brain Res 58:613-616.

Glazewski S, Chen C-M, Silva A, Fox K (1996) Requirement for $\alpha$-CaMKII in experience-dependent plasticity of the barrel cortex. Science 272:421-423.

Goldenring JR, McGuire Jr JS, DeLorenzo RJ (1984) Identification of the major postsynaptic density protein as homologous with the major calmodulin-binding subunit of a calmodulin-dependent protein kinase. J Neurochem 42:1077-1084.

Gordon JA, Cioffi D, Silva AJ, Stryker MP (1996) Deficient plasticity in the primary visual cortex of $\alpha$-calcium/calmodulin-dependent protein kinase II mutant mice. Neuron 17:491-499.

Hanley RM, Means AR, Ono T, Kemp BE, Burgin K, Waxham EN, Kelly PT (1987) Functional analysis of a complementary DNA for the 50kilodalton subunit of calmodulin kinase II. Science 237:293-297.

Hendry SHC, Jones EG (1986) Reduction in number of immunostained GABAergic neurones in deprived-eye dominance columns of monkey area 17. Nature 320:750-753.

Hendry SHC, Kennedy MB (1986) Immunoreactivity for a calmodulindependent protein kinase is selectively increased in macaque striate cortex after monocular deprivation. Proc Natl Acad Sci USA 83:1536-1540.

Hendry SHC, Yoshioka T (1994) A neurochemically distinct third channel in the macaque dorsal lateral geniculate nucleus. Science 264:575-577.

Hendry SHC, Jones EG, Burstein N (1988) Activity-dependent regulation of tachykinin-like immunoreactivity in neurons of monkey visual cortex. J Neurosci 8:1225-1238.

Hendry SHC, Huntsman MM, Vinuela A, Mohler H, deBlas AL, Jones EG (1994) $\mathrm{GABA}_{\mathrm{A}}$ receptor subunit immunoreactivity in primate visual cortex: distribution in macaques and humans and regulation by visual input in adulthood. J Neurosci 14:2383-2401.

Hof PR, Morrison JH (1995) Neurofilament protein defines regional patterns of cortical organization in the macaque monkey visual system: a quantitative immunohistochemical analysis. J Comp Neurol 352:161-186.

Hof PR, Nimchinsky EA, Morrison JH (1995) Neurochemical phenotype of corticocortical connections in the macaque monkey: quantitative analysis of a subset of neurofilament protein-immunoreactive pro- jection neurons in frontal, parietal, temporal, and cingulate cortices. J Comp Neurol 362:109-133.

Hubel DH, Wiesel TN (1972) Laminar and columnar distribution of geniculo-cortical fibers in the macaque monkey. J Comp Neurol 146:421-450.

Huntsman MM, Isackson PJ, Jones EG (1994) Lamina-specific expression and activity-dependent regulation of seven $\mathrm{GABA}_{\mathrm{A}}$ receptor subunit mRNAs in monkey visual cortex. J Neurosci 14:2236-2259.

Jones EG (1988) Modern views of cellular thalamic mechanisms. In: Cellular thalamic mechanisms (Bentivoglio M, Spreafico R, eds), pp 1-22. Amsterdam: Elsevier.

Jones EG, Hendry SHC, DeFelipe J, Benson DL (1994a) GABA neurons and their role in activity-dependent plasticity of adult primate visual cortex. In: Cerebral cortex, Vol 10, Primary visual cortex in primates (Peters A, Rockland K, eds), pp 61-140. New York: Plenum.

Jones EG, Huntley GW, Benson DL (1994b) Alpha calcium/calmodulindependent protein kinase II selectively expressed in a subpopulation of excitatory neurons in monkey sensory-motor cortex: comparison with GAD-67 expression. J Neurosci 14:611-629.

Kelly PT, McGuinness TL, Greengard P (1984) Evidence that the major postsynaptic density protein is a component of a $\mathrm{Ca} 2+/$ calmodulindependent protein kinase. Proc Natl Acad Sci USA 81:945-949.

Kennedy MB, Bennett MK, Erondu NE (1983) Biochemical and immunochemical evidence that the "major postsynaptic density protein" is a subunit of a calmodulin-dependent protein kinase. Proc Natl Acad Sci USA 80:7357-7361.

Kirkwood A, Bear MF (1994) Hebbian synapses in visual cortex. J Neurosci 14:1634-1645.

Kirkwood A, Silva A, Bear MF (1997) Age-dependent decrease of synaptic plasticity in the neocortex of a CaMKII mutant mice. Proc Natl Acad Sci USA 94:3380-3383.

Levitt JB, Yoshioka T, Lund JS (1994) Intrinsic cortical connections in macaque visual area V2: evidence for interaction between different functional streams. J Comp Neurol 342:551-570.

Liang F, Isackson PJ, Jones EG (1996) Stimulus-dependent, reciprocal up- and down-regulation of glutamic acid decarboxylase and $\mathrm{Ca}^{2+}$ calmodulin-dependent protein kinase II gene expression in rat cerebral cortex. Exp Brain Res 110:163-174.

Liang FY, Jones EG (1997) Differential and time-dependent changes in gene expression for type II calcium/calmodulin-dependent protein kinase, $67 \mathrm{kDa}$ glutamic acid decarboxylase, and glutamate receptor subunits in tetanus toxin-induced focal epilepsy. J Neurosci 17:2168-2180.

Lin CR, Kapiloff MS, Durgerian S, Tatemoto SK, Russo AF, Hanson P, Schulman H, Rosenfeld MG (1987) Molecular cloning of a brainspecific calcium/calmodulin-dependent protein kinase. Proc Natl Acad Sci USA 84:5962-5966.

Livingstone M, Hubel D (1988) Segregation of form, color, movement, and depth: anatomy, physiology, and perception. Science 240:740-749.

Livingstone MS, Hubel DH (1982) Thalamic inputs to cytochrome oxidase-rich regions in monkey visual cortex. Proc Natl Acad Sci USA 779:6098-6101.

Livingstone MS, Hubel DH (1987a) Connections between layer 4B of area 17 and thick cytochrome oxidase stripes of area 18 in the squirrel monkey. J Neurosci 7:3371-3377.

Livingstone MS, Hubel DH (1987b) Psychophysical evidence for separate channels for the perception of form, color, movement, and depth. J Neurosci 7:3416-3468.

Liu X-B, Jones EG (1996) Localization of alpha type II calcium calmodulin-dependent protein kinase at glutamatergic but not gamma$N$-butyric acid (GABAergic) synapses in thalamus and cerebral cortex. Proc Natl Acad Sci USA 93:7332-7336.

Liu X-B, Jones EG (1997) Localization of $\alpha$-type II calcium/ calmodulin-dependent protein kinase specifically at glutamatergic synapses in rat hippocampus. NeuroReport 8:1475-1479.

Lund JS, Lund RD, Hendrickson AE, Bunt AH, Fuchs AF (1975) The origin of efferent pathways from the primary visual cortex, area 17, of the macaque monkey as shown by retrograde transport of horseradish peroxidase. J Comp Neurol 164:287-304.

Lund JS, Yoshioka T, Levitt JB (1994) Substrates for interlaminar connections in area VI of macaque monkey cerebral cortex. In: Cerebral cortex, Vol 10, Primary visual cortex in primates (Peters A, Rockland $\mathrm{K}$, eds), pp 37-60. New York: Plenum.

Malenka RC, Kauer JA, Perkel DJ, Mauk MD, Kelly PT, Nicoll RA, Waxham MN (1989) An essential role for postsynaptic calmodulin 
and protein kinase activity in long-term potentiation. Nature 340:554-557.

Malinow R, Madison DV, Tsien RW (1988) Persistent protein kinase activity underlying long-term potentiation. Nature 335:820-824.

Malinow R, Schulman H, Tsien RW (1989) Inhibition of postsynaptic PKC or CaMKII blocks induction but not expression of LTP. Science 245:862-866.

Mayer P, Mohlig M, Schatz H, Pfeiffer A (1993) New isoforms of multifunctional calcium/calmodulin-dependent protein kinase II. FEBS Lett 333:3185-3188.

Murray KD, Gall CM, Benson DL, Jones EG, Isackson PJ (1995) Decreased expression of the alpha subunit of $\mathrm{Ca} 2+/$ calmodulindependent protein kinase type II mRNA in the adult rat CNS following recurrent limbic seizures. Mol Brain Res 32:221-232.

Nghiem P, Saati SM, Martens CL, Gardner P, Schulman H (1993) Cloning and analysis of two new isoforms of multifunctional $\mathrm{Ca}^{2+}$ calmodulin-dependent protein kinase. Expression in multiple human tissues. J Biol Chem 268:5471-5479.

Sakagami H, Kondo H (1993) Differential expression of mRNAs encoding gamma and delta subunits of $\mathrm{Ca} 2+/$ calmodulin-dependent protein kinase type II (CaM kinase II) in the mature and postnatally developing rat brain. Mol Brain Res 20:51-63.

Scholz WK, Baitinger C, Schulman H, Kelly PT (1988) Developmental changes in $\mathrm{Ca}^{2+} /$ calmodulin-dependent protein kinase II in cultures of hippocampal pyramidal neurons and astrocytes. J Neurosci 8:1039-1051.

Schworer CM, Rothblum LI, Thekkumkara TJ, Singer HA (1993) Identification of novel isoforms of the $\mathrm{d}$ subunit of $\mathrm{Ca}^{2+} /$ calmodulindependent protein kinase II. Differential expression in rat brain and aorta. J Biol Chem 268:14443-14449.

Silva AJ, Stevens CF, Tonegawa S, Wang Y (1992) Deficient hippocampal long-term potentiation in $\alpha$-calcium-calmodulin kinase II mutant mice. Science 257:201-205.

Stanton PK, Gage AT (1996) Distinct synaptic loci of $\mathrm{Ca}^{2+} /$ calmodulin- dependent protein kinase II necessary for long-term potentiation and depression. J Neurophysiol 76:2097-2101.

Stevens CF, Tonegawa S, Wang Y (1994) The role of calciumcalmodulin kinase II in three forms of synaptic plasticity. Curr Biol 4:687-693.

Takaishi T, Saito N, Tanaka C (1992) Evidence for distinct neuronal localization of gamma and delta subunits of $\mathrm{Ca}^{2+} /$ calmodulindependent protein kinase II in the rat brain. $\mathrm{J}$ Neurochem 58:1971-1974.

Tighilet B, Huntsman MM, Hashikawa T, Murray KD, Isackson PJ, Jones EG (1998) Cell-specific expression of type II calcium/dependent protein kinase isoforms and glutamate receptors in normal and visually deprived lateral geniculate nucleus of monkeys. J Comp Neurol 390:278-296.

Tobimatsu T, Fujisawa H (1989) Tissue-specific expression of four types of rat calmodulin-dependent protein kinase II mRNAs. J Biol Chem 264:17907-17912.

Tobimatsu T, Kameshita I, Fujisawa H (1988) Molecular cloning of the cDNA encoding the third polypeptide (gamma) of brain calmodulindependent protein kinase II. J Biol Chem 263:16082-16086.

Trojanowski JQ, Jacobson S (1976) Area and laminar distribution of some pulvinar cortical efferents in rhesus monkey. J Comp Neurol 169:371-391.

Tsumoto T (1992) Long-term potentiation and long-term depression in the neocortex. Prog Neurobiol 209:209-228.

Weber JT, Huerta MF, Kaas JH, Harting JK (1983) The projections of the lateral geniculate nucleus of the squirrel monkey: studies of the interlaminar zones and the S layers. J Comp Neurol 213:135-145.

Yamauchi T, Ohsako S, Deguchi T (1989) Expression and characterization of calmodulin-dependent protein kinase II from cloned cDNAs in Chinese hamster ovary cells. J Biol Chem 264:19108-19116.

Yukie M, Iwai E (1981) Direct projection from the dorsal lateral geniculate nucleus to the prestriate cortex in macaque monkeys. J Comp Neurol 201:1-14. 